\title{
A Preliminary Survey of the Eastern Harbor, Alexandria, Egypt, Including a Comparison of Side Scan Sonar and Remote Viewing
}

\author{
Stephan A. Schwartz \\ The Mobius Group \\ HAROLd E. Edgerton \\ Radio Strobe Laboratory, Massachusetts Institute of Technology
}

Submitted April 20, 2020; Accepted April 16, 2021; Published September 30, 2021

https://doi.org/10.31275/20211815

Creative Commons License CC-BY-NC

Abstract-This paper reports a preliminary survey of one of humanity's most historic harbors, Alexandria, Egypt. It constitutes one phase of a broader joint land/sea examination of the largest and most famous city to bear Alexander the Great's name. The research overall had two goals: 1) To resolve locational uncertainties concerning the city's past configuration, particularly its Ptolemaic antecedents; and, 2) to compare electronic remote sensing survey technologies with Remote Viewing generally, and the applications methodology developed by the Mobius Group, specifically. In the area of the Eastern Harbor, the aim of the research was: 1) The location of the ancient shoreline; the location and predictive description of several sites including: the island of Antirrhodus and the Emporium / Poseidium / Timonium complex; a palace complex associated with Cleopatra; and, a further elaboration, both in terms of location and predictive description, of the Pharos lighthouse area. 2) A comparison of remote viewing and side scan sonar data after each approach had surveyed the same area. This paper describes the probable location of the Emporium, the Poseidium, and the Timonium, the palace complex of Cleopatra, the island of Antirrhodus, a site at the tip of Fort Sisila (known previously as Point Lochias), new discoveries pertaining to the lighthouse, and an associated temple. The most important discovery though is the identification and location of the ancient seawall which extends some 65 meters farther out into the harbor than was previously suspected, and whose location resolves a key piece in the puzzle of the ancient city's layout. The discoveries reported were principally the result of Remote Viewing. Except for one clear "hit," side scan sonar proved unproductive because of the large amount of particulate in the water. 


\section{INTRODUCTION}

In 331 BCE, Alexander of Macedonia stopped at a small fishing village on Egypt's Mediterranean coast and marked out the boundaries of what would become the greatest city to bear his name. From the first, its destiny was tied to the sea (Arrian, 1942, p. 468). Its founder appreciated this and fixed its location believing, as Arrian reports, that because of the sea, "the site was the best possible for the foundation of a city and the city would prosper" (Arrian, 1942, p. 467). To achieve his ends, one of Alexander's highest priorities was the creation of what has come to be known as The Eastern Harbor.

How sound was Alexander's judgment? From its Western and Eastern harbors, Alexandria soon supplied the world with grain, with glass, and with precious metals. Strabo of Amasya in Pontius, whose Geography describes the city three centuries after its founding, provides us with an assessment from antiquity: ". . . the only place in all Egypt which is by nature situated with reference both to commerce by sea, on account of the good harbors, and to commerce by land, because the river [Nile] easily conveys and brings together everything ... [Alexandria] is the greatest trading center of the inhabited world" (Strabo, 1949, p. 53).

Fraser, writing two thousand years later, offered a modern assessment of that period that is little different: "Alexandria in the late Ptolemaic period was the unrivaled center of world trade" (Fraser, Vol. 1, 1972, pp. 133-188). ${ }^{1}$

Today, although Alexandria is Egypt's second-largest city, the Eastern Harbor is no longer a great port. Yet, as this paper describes, diving in those waters was entering into an ancient past that held answers to myriad unsolved archaeological riddles. The detritus of almost two-and-a-half millennia of commerce has accumulated on the harbor's sea floor. Due to subsidence of the shoreline, to depths as great as eight meters, a considerable number of the ancient city's most famous buildings-structures associated with the now mythic figures of Cleopatra, Mark Antony, and Caesar-now lie submerged. ${ }^{2}$ What was also important, in 1979 when we did this work, is that they lay relatively undisturbed, unlike the archaeological chaos to be found on the shore, where earth-moving and construction has been constantly ongoing since 1882 , when the modern city emerged. ${ }^{3}$ 


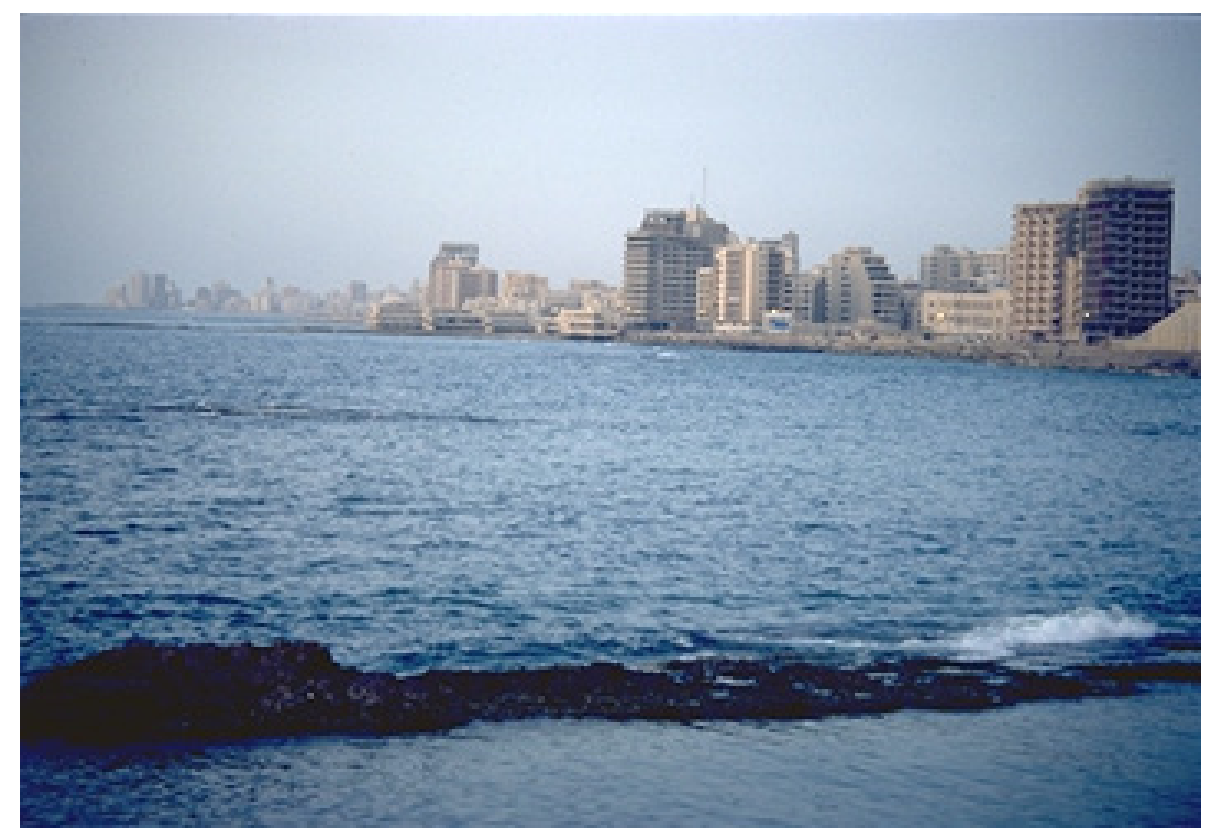

Figure 1. The Eastern Harbor as it appeared when the Mobius Expedition began.

In November of 1978, the Mobius Group began designing a project using remote viewing to guide archaeological fieldwork in Alexandria. As the paper describes, the project began in Los Angeles, California, and it was there, long before anyone involved had gone to Alexandria, that the first remote viewing probe was carried out, and the data, and the master map it produced, helped in developing a set of hypotheses concerning both location and reconstructive data. That led to planning a preliminary survey of the harbor, an area, as one looks outward toward the sea, limited on the west by a man-made peninsula known as the Heptastadium, associated since antiquity with the Lighthouse of Pharos and, on its eastern bound, by a smaller, natural, although much altered peninsula known today as Fort Sisila and, previously, as Point Lochias (see Figure 1 and Figure 3).

This harbor research constituted one segment of a broader joint land/sea examination of Alexandria. The research overall had two goals: 
1) To resolve locational uncertainties concerning the city's past configuration, particularly its Ptolemaic antecedents; and,

2) To compare data derived from electronic remote sensing technologies both marine and terrestrial such as side scan sonar and ground-penetrating radar, with a triple-blind technique for accessing nonlocally sourced information known as remote viewing. And to do this using the applications consensus methodology developed by the Mobius Group. (In this paper, remote sensing means electronic instrument sensing.)

In the area of the Eastern Harbor, the aim of the research was:

1) The location of the ancient shoreline; the location and predictive description of several sites including: the island of Antirrhodus and the Emporium / Poseidium / Timonium complex; a palace complex associated with Cleopatra; and, a further elaboration, both in terms of location and predictive description, of the Pharos lighthouse area, one of the seven wonders of the ancient world.

2) A comparison of Remote Viewing and side scan sonar data after each approach had surveyed the same area.

\section{LITERATURE REVIEW}

Strabo, who visited the city in $24 \mathrm{BCE}$, in the first decade of Roman rule, gives the best description of Alexandria and its harbors at their height. He says that while Dinocrates was the primary architect, he followed a well-tested urban plan developed by Hippodemus of Mieltus, and previously used in Priene and Herculaneum (Fakharani, 1974). Alexander apparently had admired it because it made for an urban environment with good air and traffic flow patterns and produced a city with a sense of graciousness. Arrian tells us that Alexander himself outlined the city's walls (Arrian, 1942, Vol. 2, pp. i, ii).

Ancient Alexandria was roughly rectangular in shape. Strabo calls it "an outspread chlamys" - the cloaklike garment favored by Greek travelers and soldiers (Strabo, 1949, p. 33). He says it was built along the sea and spread out 30 stadia $(1$ stade $=185 \mathrm{~m})$ in length $(5.55 \mathrm{~km})$ and seven to eight in width (1.29-1.48 km), with indentations on the long sides caused by the harbors on the north, and Lake Mareotis on the south (Strabo, 1949, p. 33). The key to the city's layout was its two major 
streets, which intersected at right angles, and were "particularly wide, being more than a plethron (30 m) in width" (Strabo, 1949, p. 33). This planned urban community must have been very beautiful, particularly along the sea frontage, which was filled with shaded groves and mansions, intermingling with public buildings. Unfortunately, almost all of this city has been lost, either beneath subsequent constructions, or because of subsidence, and so visually the city described in the literature of antiquity exists today mostly in the writings themselves.

When we began our research, although there was a fairly extensive modern literature on Alexandria, the scholarly writing addressing its archaeology and geography was much smaller than one would have expected for a city of its prominence in the ancient world. And much of what did exist dated to before World War II. Only the University of Warsaw had an active continuous archaeological presence, one they had maintained for the previous 20 years, and the totality of all previous marine archaeological work consisted of hobby-ist divers and of a few dives carried out around Kait Bey in 1962 by the Egyptian Navy (which resulted in the raising of a 7 -meter-long broken statue of a female figure), ${ }^{4}$ and six dives in the same area, in 1968 , by a joint UNESCO/ English team as reported by Frost (1975). ${ }^{5}$

It is also worth noting that all of this previous underwater work stemmed not from anything in the literature but from a Customs House official and amateur scuba enthusiast, Kemal Abu al Saadat, the most knowledgeable antiquities diver in Alexandria, who had reported to local archaeologists what he had seen.

Three main themes weave their way through the modern archaeological and geographical record that does exist:

1. Cycles of habitation: Mobius researchers were startled to discover living individuals who remembered much of the city, particularly east of the Eastern Harbor, as virtually a desert. ${ }^{6}$ Unlike Rome, the metropolis with which it is often compared, Alexandria has not enjoyed continuous inhabitation since its beginnings, and the hallmark of Alexandrian literature is a recurring cycle of downfalls and resurgences that have occurred, as a march of very different cultures have sequentially put their stamp upon the city.

The literature makes it clear that this almost constant churning has left such confusion that one of the most vexing questions has 
been exactly where and with what orientation the two main streets of the original city were to be found (Fraser, 1972, Vol. 1, p. 10). Modern authorities have achieved a rough consensus that the east-west street is approximately paralleled by the present day Sharia El Houriya (in common usage, Rue Houriya; Fraser, 1972, Vol. 1, p. 31). The location of the north-south street is less clear. Fraser, who has studied the question as thoroughly as anyone, concluded in 1961, that the entire issue was so muddled as to admit to no definitive answer (Fraser, 1972, Vol. 1, p. 31).

2. Subsidence: Throughout its recorded history Alexandria has been (rather more in the past than now) a geologically active area. Beginning with Strabo and coming forward in time, almost every writer who has dealt with Alexandria's topography includes discussions of seismic activity and its possible effects on the undeniable and very substantial subsidence of the coast. Jondet, as in the case of most of the issues pertaining directly to the ports of Alexandria, seems to be the best source (Jondet, 1916, 1922), although Saint-Genis, the Napoleonic era Harbor Master, makes many valuable contributions in this regard (Saint-Genis, 1817).

In addition to seismic activity, the reasons offered for the subsidence of Africa's Mediterranean littoral range from the weight of silt coming from the Nile mouth at nearby Rosetta, to a shift in the African plates. Subsidence is such a critical issue because the two most important centers of the pre-Islamic city, the Royal and Administrative Quarters, were to be found along the shore (Saint-Genis, 1817). But where was the ancient shoreline?

When we arrived in Alexandria, there was not a single diving archaeologist in the city. As a result, coastal subsidence evidence for the location of the ancient harbor shoreline was limited to just a few particularly prominent features visible looking down from the surface. There was an ongoing discussion as to where the ancient seawall was located, because that would affect the geography of the entire Ptolemaic city. Because of a third factor, this fundamental question had not been answered.

3. Reconstruction: Beginning with the Khedival government in the midnineteenth century, an entirely new and almost completely artificial shoreline has been constructed, as a substantial part of the existing literature describes. ${ }^{7}$ As a result, as Fraser has it, "It is true we 
know that certain buildings, public places, and so on were planned or built or recorded as having been planned or built, by certain historian figures, but the evidence is so disconnected and at times so unreliable, that no complete picture emerges...." (Fraser, 1972, Vol. 1, p. 36).

\section{ELECTRONIC REMOTE SENSING \& REMOTE VIEWING IN ARCHAEOLOGY}

\section{Side Scan Sonar}

In this instance the correct remote sensing technology to survey the harbor electronically, to compare with the remote viewing data, was side scan sonar. It emits recurrent flashes of acoustic energy into a body of water and then records the echoes that produces. It can provide location, but only limited descriptive data.

In the Eastern Harbor, the side scan survey was accomplished by Professor Harold Edgerton, Chairman of the Radio Strobe Laboratory, Massachusetts Institute of Technology. Edgerton is considered the father of this kind of survey. He worked using an EG\&G Model 259 side scan sonar, and Mark 1B System Tow-Fish, both specially modified to Edgerton's specifications by $E G \& G^{8}$ (see Figure 2).

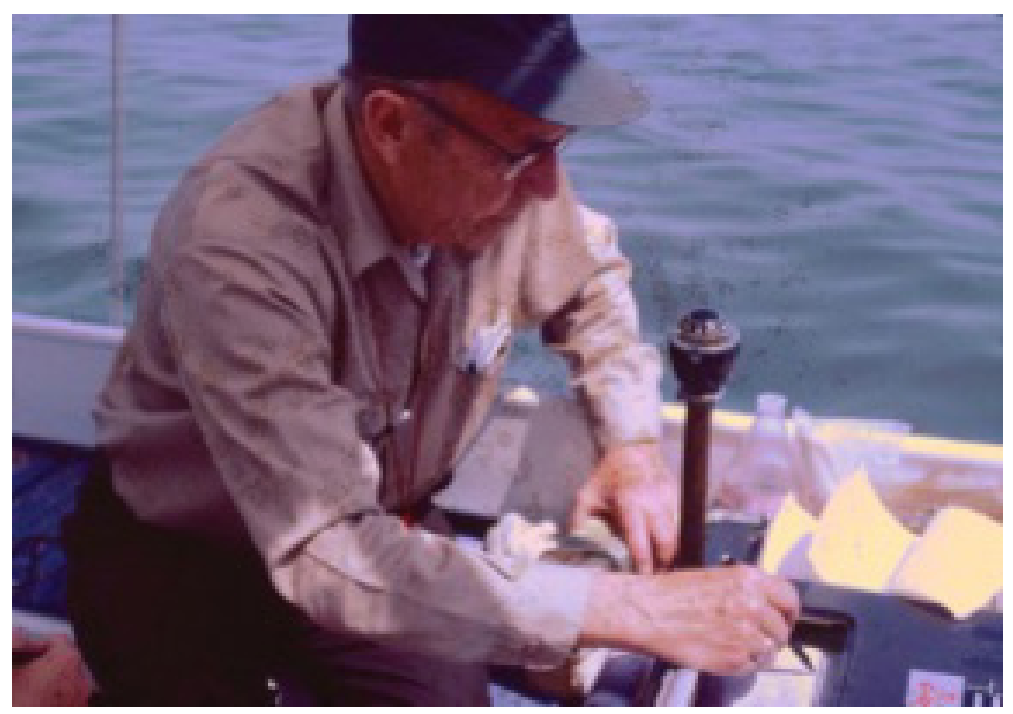

Figure 2. Harold Edgerton carrying out the side scan sonar survey. 


\section{Remote Viewing}

Remote viewing and electronic remote sensing, while radically different technologies, have one thing in common: Both have the ability to pinpoint under triple-blind conditions the location of a previously unknown as to its location, but possibly known to exist, archaeological site. In this respect they are each variations of an information acquisition technology.

Nonlocal perception is a technique for acquiring information that can be objectively verified, accessed through a nonphysiologically based nonlocal aspect of consciousness. Remote viewing is the formalized protocol for doing this. There are several variations as to how it is done, all developed by three research centers: Mobius, the research group that carried out the expedition described in this paper, Stanford Research Institute (SRI), which did largely classified research for military and intelligence agencies, and the Princeton University Engineering Anomalies Research Group (PEAR). They worked largely independent of one another but in a complementary way (Schwartz, 2017). All three had presented and published papers at the time of this research, demonstrating under the most rigorous conditions the reality of nonlocal perception using remote viewing in both laboratory and practical applications (Targ \& Puthoff, 1974; Puthoff \& Targ, 1976).

With remote viewing in archaeological applications, it is possible to get accurate locational information and also highly detailed descriptive information concerning what is to be found at that location. In doubleor triple-blind meticulously randomized remote viewing sessions, individuals have demonstrated they can reliably describe persons, places, or events from which they are shielded by virtue of space, time, and "blindness" protocols.

They do so in much the same way an eyewitness would recount the memory of something they had witnessed. All their senses report; that is, viewers can answer questions that involve smells, sounds, colors, shapes, textures, even tastes. The mechanism of this perception is unknown. But that it can be used in archaeology is demonstrated by this paper.

The task of the researcher is to structure the interview session in such a way that normal sensory cues are absent, and that intellectual 
access is eliminated. The researcher in an applied remote viewing experiment such as this is blind to the correct information; indeed, by definition, everyone is, that is why the questions are being asked.

Although this process may seem unusual, in fact researchers are essentially faced with a novel presentation of a familiar engineering problem: extracting from a weak information channel. In the case of side scan sonar, the "noise" is particulate matter in the water, schools of fish, and the like. In remote viewing the information channel is not a signal in the electromagnetic sense. It is more like doing a Google search. In this analogy, the search term is intentioned, focused awareness on a task. Just as the quality of the side scan instrument makes a difference, so the key to successful remote viewing is the ability to attain, and sustain intentioned focused awareness, so that one can perceive the weak nonlocal information buried in the noise of the sense impressions of the body's neuroanatomy, and the cognition it provokes. In this instance, normal sensory awareness and prior knowledge constitute the "noise."

Meditators generally do better at attaining and sustaining intentioned focused awareness, which is the key to opening to nonlocal perception, than nonmeditators, which may be why meditation is taught in Japanese dojos, and in Tibetan and Christian monasteries.

The use of nonlocal perception in archaeology entered the literature over a century ago with Frederick Bligh Bond's successful exploration and reconstruction of Glastonbury Cathedral in England (Schwartz, 1978b, pp. 1-56, 354-355 [Bibliography]). It has continued periodically (albeit infrequently) down through the years. Examples are ethnographer Stanislaw Poniatowski's work in Poland (pp. 57-107, 354-355 [Bibliography]), Scott-Elliot's in England (pp. 108-127, 355-356 [Bibliography]), Pluznikov in the (then) Soviet Union (pp. 127-135, 355-356 [Bibliography]) in Schwartz (1978b); and Weiant's with the Smithsonian at Tres Zapotes (Schwartz, 1978a, pp. 222-238; Weiant, 1943, 1960); and Reid's work at Ontario Iroquois sites (which used George McMullen, $\mathrm{R}_{3}$, who was a viewer in this Alexandrian project; Schwartz, no date, pp. 211-221). All of this exploration, other than that of Mobius', used variations of nonlocal perception techniques and all depended on the input from a single practitioner.

In 1976, the author began developing a consensual remote 
viewing methodology, using multiple respondents independently and individually responding to the same questions-in controlled conditions of intellectual and sensory blindness, which led to an expert evaluation of every concept advanced by viewers. From this information the hypotheses that guided the fieldwork were developed.

The first use of this consensual methodology in underwater archaeology is to be found in the Mobius report on a 1977 experiment series utilizing the research submersible Taurus I (Schwartz, 1979). Known as Project Deep Quest, the program was conducted by Mobius in conjunction with The Institute for Marine and Coastal Studies of the University of Southern California, and Hyco Ltd., builder of the Taurus. Archaeologically, Deep Quest demonstrated that remote viewers could locate on a map from distances away of up to 4,800 kilometers, a previously unknown wreck at $92+$ meters of depth, that no previous survey had ever located. Remote viewing was also successfully able to provide specifics, including drawings, as to what would be found at the selected site; the cause of the ship's sinking; and the approximate period in the past when the ship's sinking occurred. All points were corroborated by fieldwork, literature review, and expert analysis (Schwartz, 1979).

In addition to the archaeological aspect, Deep Quest had another purpose: To answer a question then widely held-was nonlocal perception electromagnetic in nature? To carry out this part of Deep Quest, the author invited researchers from SRI to participate. That experiment showed that nonlocal perception was not electromagnetic in nature (Schwartz, 1978a).

From a remote viewing perspective, the question of the seawall's location provided an ideal triple-blind protocol. Everyone agreed there was an ancient seawall. But everyone also agreed that no one knew exactly where it was located. And the same was true of the areas selected by the remote viewers before the fieldwork began. Cleopatra had a palace somewhere on the harbor coast, as did Marc Antony. The Lighthouse of Pharos, one of the seven wonders of the ancient world, was known to exist but was unfound. And all of these things had been predicted in the Map Probe phase. 


\section{Comparison of Electronic Remote Sensing and Remote Viewing Data}

Mobius remote viewing archaeological projects are designed with a second research aspect: Comparing electronic remote sensing with nonlocal perception remote viewing: This was one of the research objectives of the Alexandria Project. In addition to comparing the data, we also sought to develop a complementary approach that would use both survey techniques in order to provide researchers with the highest quality fieldwork guidance. This team approach was designed to help improve the information-to-noise ratio previously described. The remote viewers functionally are the survey instruments, and using more than one on the same site is the equivalent of having multiple electronic sensors-side scan sonar, proton precession magnetometer (as examples)—survey an area and then collectively define what is there. Thus, as the paper reports, had we relied entirely on electronic remote sensing, the paper would be very different. Thus, the "best case" scenario relying exclusively on electronic remote sensing can be considered the "worst case" for the combined methodology.

\section{MOBIUS GROUP METHODOLOGY}

Mobius conducted its Remote Viewing in the following way:

\section{Phase One Methodology}

1) The Remote Viewing team was selected, and each individual Respondent was given an anonymous alphanumeric designator, i.e., R1. This was done to minimize the possible impact of various conceivable researcher biases, by depersonalizing the source of the data.

2) Sessions were done either in person at Mobius' Los Angeles, California, location, or else numbered manila envelopes were sent to distant viewers, each envelope containing one question, except one that contained a map. In this first phase, because we had been told by the Egyptian government that no diving was permitted in the Eastern Harbor, our focus was entirely on terrestrial sites. The viewers answered the questions in the envelopes and made their locations on a standard U.S. Army Map Service chart (1:10,000) that had been specially prepared by having the typical multiple colors-which might provide false "cueing"-eliminated and many place names removed. This was done 


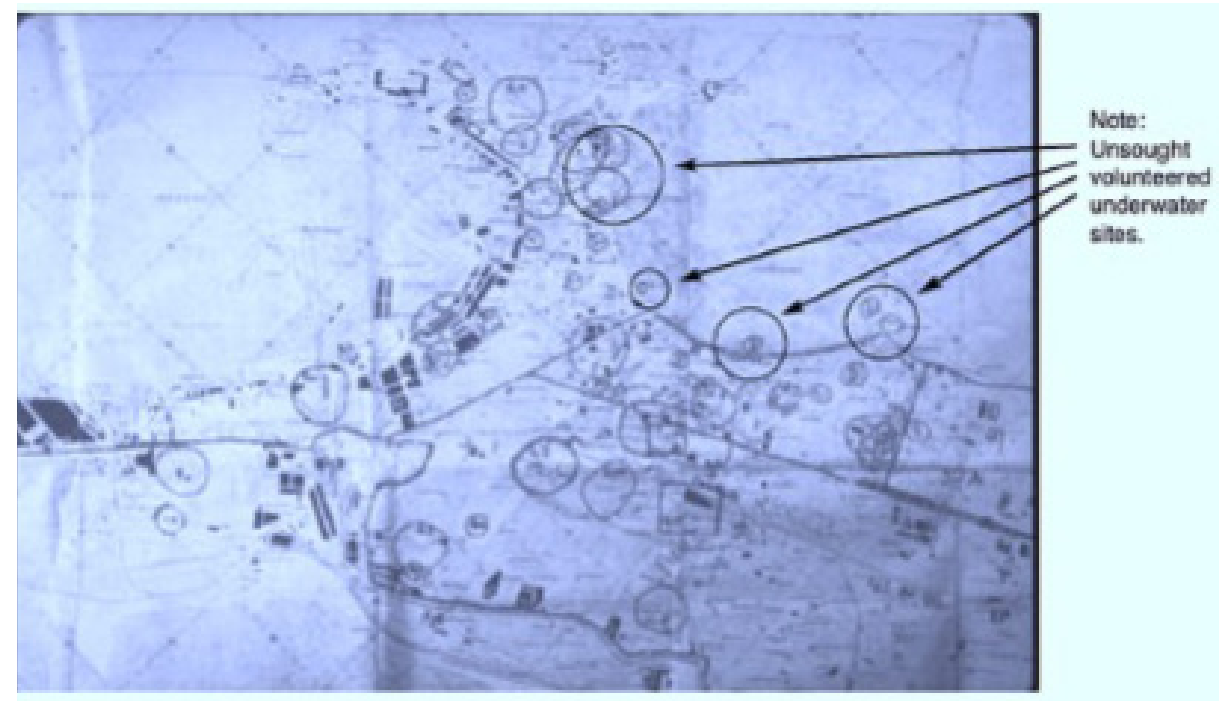

Figure 3. The Master Composite Map from Probe One. Note the lack of color and deletion of most place names. Also note where the individual locations overlap. These were called Consensus Zones and given priority in fieldwork.

by producing a Mylar master which was then "blueprinted," producing a simple line map of uniform color. This packet was sent to 11 Respondents.

3) The data-gathering Remote Viewing sessions took place. Some were conducted as interviews in person, others were conducted through the mail. Each question began with a location request. The viewer marked their response on their chart, followed by a request for descriptive material concerning what would be found at the site chosen, e.g., "If you could locate a construction, ruin, or artifact associated with the famous woman in history known as Cleopatra where would you look and if you could describe what you believe is there, what would it look like?" (Question \#1, Probe II, October, 17, 1979). The form of the question was designed so that nothing "cued" any particular descriptive response or site selection.

4) A composite map including all the information contained on the individual maps was then developed. Where the individual location marks from the various Respondents overlapped, Consensus Zones were created. In the Fieldwork Phase, these zones would later be given first priority, although all marked areas would be explored. To our surprise, in answer to some of the questions, particularly those involving Cleopatra and Marc Antony, viewers marked an area in the sea (see Figure 3). This suggested massive subsidence and a seawall 
much farther out than anything the literature suggested.

5) All nonlocal perception remote viewing interviews, whether done in-person, or submitted via mail, were audiotaped. Once collected, these tapes were transcribed.

6) Copies of all paperwork or tapes were made, and the originals were then notarized and turned over to an independent third party. (In this case all original documentation was in the hands of a bank officer in Los Angeles and stored in the bank's vault.) This produced an unimpeachable date-coded chain establishing a clear chronology of events (see Figure 4).

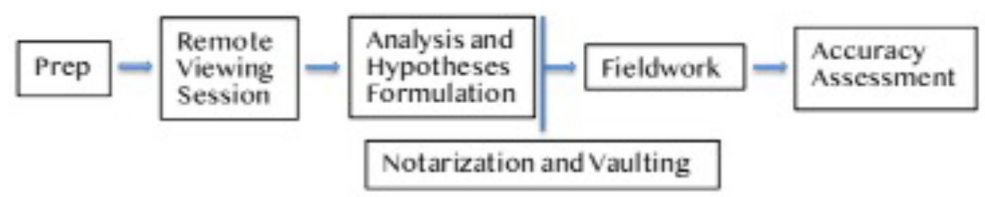

Figure 4. Chronology of study events.

7) Working from the photocopies of the original probe responses, the Remote Viewing Research Team then analyzed the proffered Remote Viewing material seeking, in the words and drawings, patterns of commonality, or something so odd that it stood out. These patterns are not imposed but arise from the material itself. For instance, did more than one viewer choose the same site? Did one of the group provide a drawing of a particular structure at that site that was similar to another viewer's drawing? How similar were the descriptions? From this, and the Composite Map, a set of hypotheses was developed to guide the subsequent fieldwork.

8) With this phase of the analysis completed, the research concurrently done by the Archives and Records Team was integrated with the Remote Viewing data. This made it possible to establish what was previously known, which proffered Remote Sensing material coincided with known information, and which was novel. For example, if someone located a ship and described an anchor, the observation might be correct, but it would not be unexpected. If, on the other hand, they described the cargo as containing plates with particular markings, which they drew, such an observation would not be expected, and would have a low a priori probability. 
9) Since no map is detailed enough to take a location down to a level sufficient for precise excavation, two Remote Viewers went to Egypt to provide on-site guidance. Each was individually taken into the Alexandria and, without access to the maps, asked to locate a particular consensus zone. If that was successfully accomplished, they were asked to locate down to feet and, sometimes, inches, the site within the zone. Additional information relating to artifact positioning within the site, the outline of walls and other structural aspects, subsurface or underwater conditions (silting, currents, and the like) were solicited. Drawings were sought, as well as a reference to scale.

10) All of this was videorecorded and/or filmed on a real-time basis; the tapes were then transcribed and the transcriptions, original tapes, and original drawings, as with the previous data acquired in the U.S., were notarized, photocopied, and the original sent back, prior to fieldwork, for storage control by the bank officer.

11) From this second order of material, in photocopy form, additional analysis was undertaken. This was then folded into the first analysis and again compared with whatever had been gleaned from the ethno-historic, geographical, and archaeological record. This analysis, when integrated with the first, produced the hypotheses under which the subsequent fieldwork was to be conducted, as well as defining what was uniquely potentially nonlocal.

12) Prior to the remote viewing fieldwork, electronic remote sensing of the mapped area was carried out using side scan sonar.

13) Divers were put into the water at the site selected by remote viewing to survey the site.

14) Once this fieldwork was completed, a final analysis comparing predictions from both electronic sensing and Remote Viewing surveys with actual fieldwork results was developed. It was from this that the final evaluation as to the accuracy of the Remote Sensing material was determined.

\section{Phase Two Methodology}

15) A second Map Probe utilizing nine Remote Viewer Respondents was carried out focusing (as the first Map Probe did not) specifically on the Eastern Harbor and nearby coastal waters.

16) Analysis of the individual maps, and related descriptive 
material was begun prior to leaving the U.S. and completed after arrival in Egypt. A second Composite Map based on the individual maps was also compiled (see Figure 13).

17) A three-week diving program was conducted by Mobius, aided by Egyptian divers.

18) A final analysis of results was conducted, and this paper prepared.

\section{PERSONNEL}

To carry out this research program, seven teams were assembled, each having responsibility for one aspect of the research. The specialty teams were:

1) The Historical/Archaeological Team: Mustafa el Abbadi, historian, Chairman, Department of Classical Civilizations, Faculty of Arts, the University of Alexandria; Daoud Aboud Daoud, archaeologist, Professor of Archaeology, Department of Classical Civilizations, Faculty of Arts, the University of Alexandria, and Secretary of the Archaeological Society of Alexandria; Mohamed Hassan, archaeologist, Antiquities Inspector and Staff Archaeologist, Greco-Roman Museum; and Mieczyslaw Rodziewicz, archaeologist, Director, The University of Warsaw Archaeological Mission in Alexandria.

2) The Electronic Remote Sensing Team: Harold E. Edgerton, electrical engineer, Radio Strobe Laboratory, Department of Electrical Engineering and Computer Science, Massachusetts Institute of Technology; and Captain Mohamed Rashad, Armed Forces of Egypt Naval (AREN), naval hydrographic engineer, Naval Headquarters, Alexandria.

3) The Remote Viewing Research Team: Stephan A. Schwartz, parapsychologist, Mobius; Beverly Humphrey, parapsychologist, SRI; and Kathi Peoples, Mobius staff support.

4) The Remote Viewer Respondents: Most viewers who participated in the first Map Probe took part in the second. They ranged in age from early thirties to midsixties, and came from several countries, with educational backgrounds ranging from grade school to multiple advanced degrees. When not working with Mobius, the Remote Viewers individually have successful careers in fields as diverse as aeronautical engineering, automobile repair, fine arts, and writing. 
Viewers were selected on the basis of their success in past research-mostly laboratory experiments with statistical outcomesalthough the majority had participated in the Deep Quest ship location experiment.

Only one had any experience with archaeology, or even knew an archaeologist. This Respondent, George McMullen, R3, had worked for some years with Professor J. Norman Emerson of the University of Toronto's Department of Anthropology, and his student Reid (Emerson, 1975, pp. 23-25; Schwartz, 1978b, pp. 356-357 [Bibliography]).9

None of the viewers had ever been to Alexandria; none knew anything of its early history, although they were, of course, familiar, in the general way people are, with the historical personalities such as Caesar, Alexander the Great, Mark Antony, and Cleopatra.

All Remote Viewers were "blind" to the questions before these were presented to them; indeed, did not even know the project was to take place in Egypt. In any case, even had they been working archaeologists it would not have mattered much because the questions, for which the project sought answers, were well-established mysteries over which there had been much conjecture, but no resolution.

The two Respondents taken to Egypt were McMullen, $R_{3}$, and Hella Hammid, R5.

5) The Dive Team: Commander Mohamed Khaled, AREN; a changing group of enlisted navy divers; Stephan A. Schwartz; and Kathi Peoples.

6) The Archives and Records Team: Catherine Dees, historian; Kay Croissant, historian; Karen Winters, field log; David Keith, illustrator; and Jacqueline Kendall, staff support.

7) The Photography Team: Glenn Winters, land film; Bradley Boatman, land film. Gordon Waterman, underwater film; Dyanna Taylor, underwater film and still photography; Karen Winters, land still photography; and Kathi Peoples, underwater still photography.

8) The Audio Team: Sunny Meyers, audio film; Osama Salama, audio film; Stephan Schwartz, interviews; Beverly Humphrey, interviews.

The Photography and Audio Teams were established so that there would exist an unimpeachable real-time, audio-visual record of every aspect of the experiment. 


\section{ELECTRONIC REMOTE SENSING SURVEY}

Prior to conducting the side scan sonar electronic remote sensing survey, indeed prior to our departure from the United States, several Respondents had indicated possible sites in the waters in and around the Eastern Harbor and had marked them on their maps (see Figure 3).

Additional information was volunteered once we were on site, both before the work in the harbor was even thought possible (because of government restrictions) and, subsequently, but before Edgerton arrived in Egypt and fieldwork began.

We considered this volunteered underwater material to be particularly significant because no questions specifically directed toward underwater sites had been included in the initial Alexandrian probe. Experience has shown that one should pay particular attention to remote viewing data volunteered outside the scope of the questionnaire. ${ }^{10}$ Three areas of particular interest emerged in this manner (see Figure 5: ceramic target, sonar record 8:46, and the barge wreck).

A side scan survey was designed to cover all the volunteered Remote Viewing sites as well as non-RV selected areas, chosen by Edgerton, based on his best judgment, which were to act as controls. This work began on May 8, 1979, and continued for the next four days, hampered almost continuously by the extreme amount of particulate matter suspended in the water. The results were disappointing, as Edgerton's very short report makes clear:

\section{EASTERN HARBOR SIDE SCAN SURVEY By Harold Edgerton}

This report covers the use of an EG\&G side scan sonar at the Eastern Harbor of Alexandria as requested by Stephan Schwartz, Research Director of the Mobius Group, Los Angeles, California. I left Boston on May 1, 1979, taking with me an EG\&G type 259 side scan sonar which is especially useful for the underwater search areas where artifacts protrude from the sea's bottom.

A map of the Eastern Harbor of Alexandria [see Figure 5] with dotted lines indicates some of the survey paths where navigation was made by Mohamed Rashad of the Egyptian Hydrographic Service. He used two sextants that read onshore points.

One sonar trace, taken on May 13 from 8:46 a.m. to 8:50 a.m., corresponds with the course shown on the above chart of Eastern 
Harbor [see Figure 6]. Attention is directed to the location of the "ceramic" target which is 65 meters from the present seawall, on the east side of the harbor.

A second trace [see Figure 7] from the side scan record shows a vertical view of the same "ceramic" target since the course of the survey ship went directly over the target.

I measured the height above the sea bottom of this target to be 1.2 meters."

Why was the side scan survey so disappointing? Perhaps because of the heavy particulate in the water.

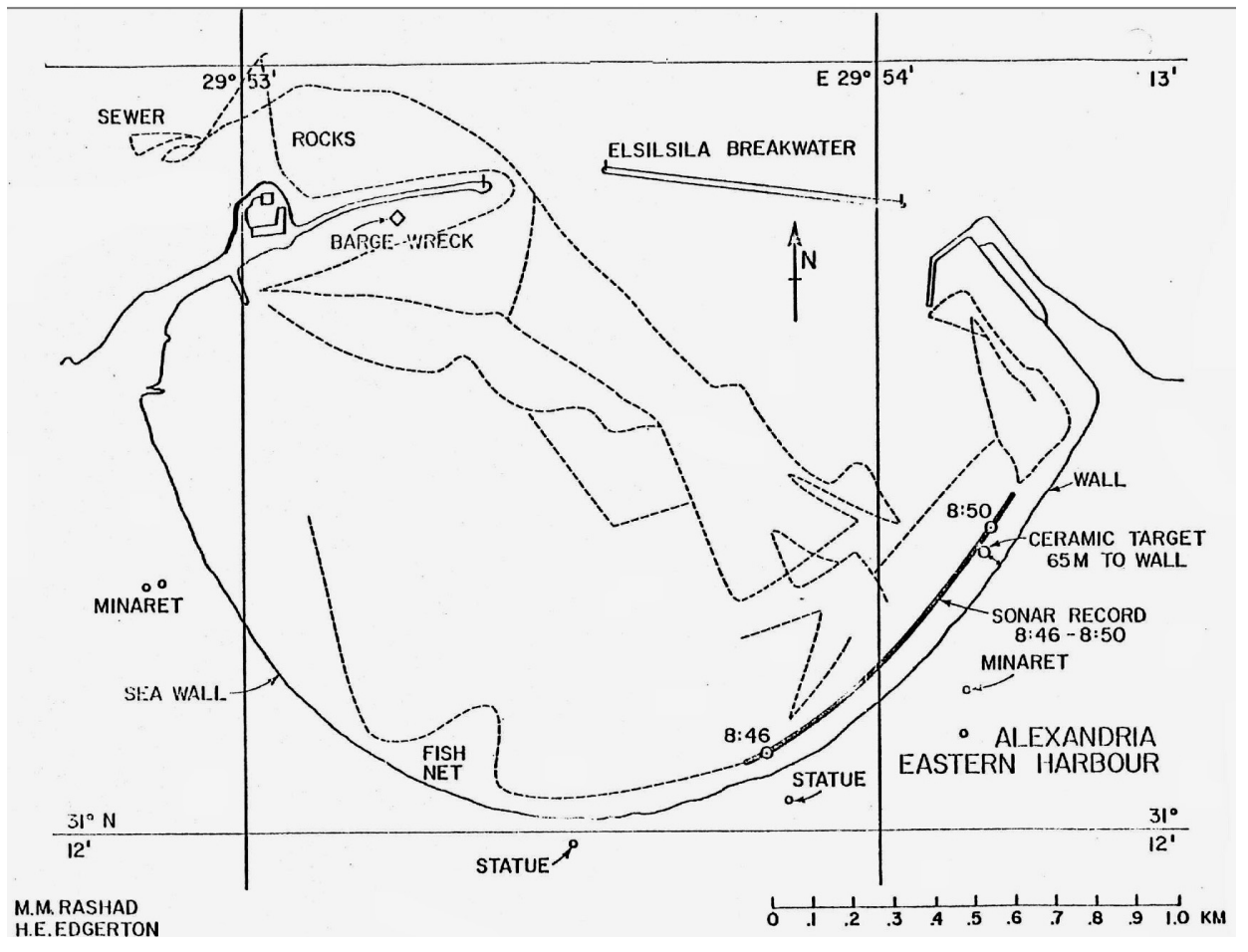

Figure 5. The side scan survey was done in such a way that it covered the sites selected by Remote Viewing, as well as non-RV selected areas, chosen by Edgerton, based on his best judgment, which were designed to act as controls. Nothing was discovered except in the RV-selected areas, and most RV sites produced no side scan "hits." 


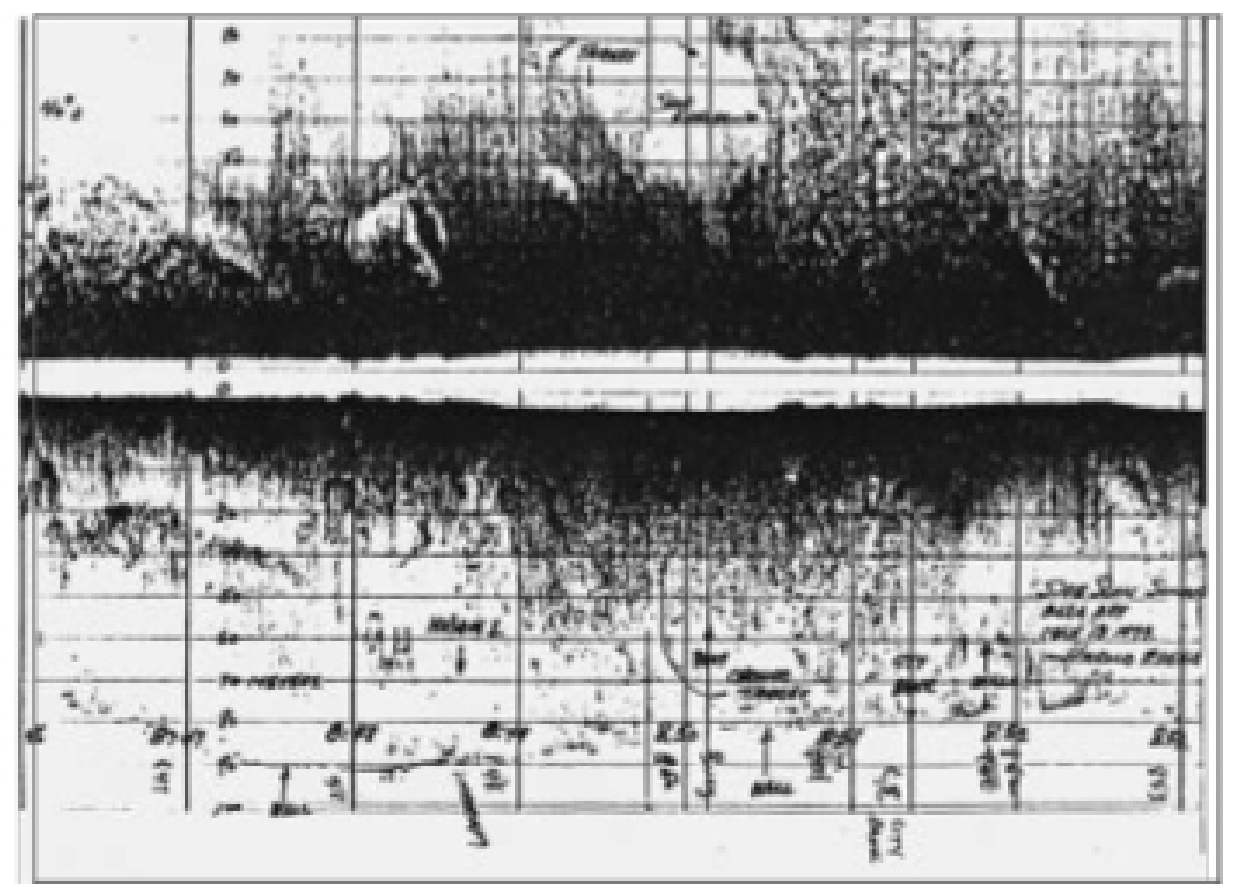

Figure 6. The side scan sonar track from 8:46 to 8:50 a.m. on the morning of May 13, 1979, showing the "ceramic" target at the site Remote Viewers felt would mark the ancient seawall. It is approximately 65 meters from an existing corniche wall and suggests that the Greco-Roman city has subsided far more than was previously appreciated.

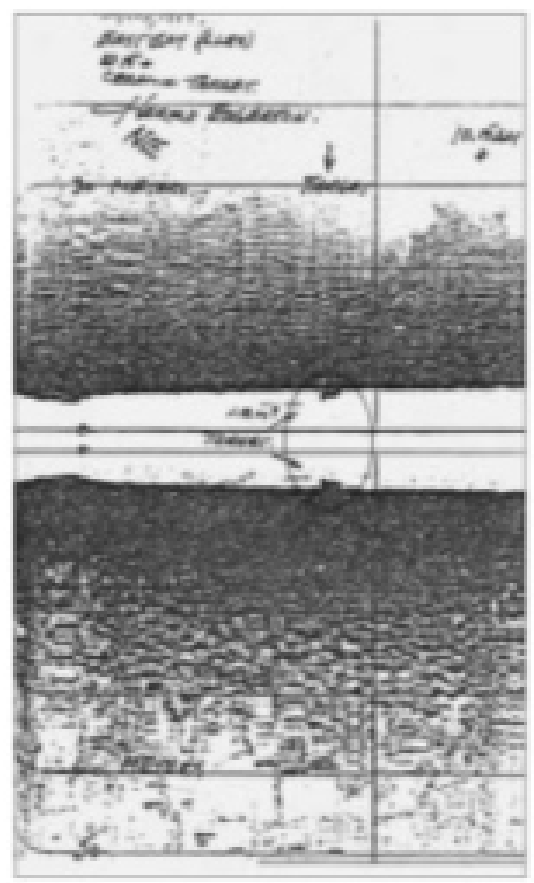

Figure 7. Side scan trace showing "ceramic" target. 


\section{PHASE ONE FIELDWORK}

During the side scan survey, we made several initial dives on sites identified by side scan electronic sensing or by Remote Viewing.

A note of caution about the precision of our locations: It proved very difficult to shoot a transit on a diver or a buoy from the shore, so some variance, measured in a few meters, must be understood. For ease of comparison between the various data sources, the sites covered by the first phase of fieldwork are presented with the following structure:

Literature Review

Side Scan Sonar

Remote Viewing

Field Observations

Summary

\section{Central Harbor, Site 8-The 8:46 Site}

Literature Review. A massive pillar was discovered at this site, and we began a search for some mention of such a large column in the classical literature sources but found nothing that could be directly correlated. Henry $\mathrm{H}$. Gorringe, a former naval officer hired to bring back one of the Cleopatra obelisks to New York, does make a reference to what we think is the same column, although it adds little and is so vague about exact location as to be useless for that purpose: “. . . about one hundred yards from the beach. [A measurement made from somewhere on the shore prior to construction of the present corniche.] There is a broken column sticking up from the bottom of the sea, nearly equal in diameter to Pompey's pillar" (Gorringe, 1882).

Side Scan. The "8:46" site was described by Edgerton and nicely outlined on the trace, demonstrating that the side scan not only tested as operating correctly, but also demonstrated that it was functioning properly (see Figure 6).

Remote Viewing. Site location volunteered by Respondent $\mathrm{R}_{3}$ with the description of a large column.

Field Observations. 8:46 proved to be a large Aswan granite column lying on its side. The dimensions of the column (about 4 meters long by 2.5 meters in diameter). No other pillar even approaching its 
dimensions was found in the vicinity. One diver reported that he could feel a base to the pillar, and the trace suggests this (not the column that may have been what the sonar registered), but we could not see it since it lay beneath a thick layer of sand and broken shells.

Nearby, perhaps 9 to $10 \mathrm{~m}$ away, and unrelated to the sonar hit, evidence of what we now believe is the ancient seawall was discovered.

The diver who first located it said it seemed "almost like ceramic" and that the fragment ran parallel to the corniche. ${ }^{11}$

Diving the next day resolved this odd description: The discovery was not, in fact, ceramic, but rather brick and stone "welded" by time and overlaid by marine growth.

Summary. This site was the one clear side scan "hit" (Figure 6 and Figure 7), although there is confusion as to whether it was the base or the column that triggered the sonar trace. The Archaeological/ Historical Team felt the column must be commemorative rather than structural, particularly since nothing else remotely like it was found at the site. We think this is the same column described by Gorringe, and the fact that it is no longer visible from the surface provides some measure of the change in the quality of the harbor over time. Beyond the find itself, the placement of the column was significant, because it supported the location of the ancient seawall as being much farther out to sea than was previously thought. As for what we now believe to be a seawall fragment: At the time, this small section was not large enough to lead to any conclusion.

\section{Central Harbor, Site 8}

Literature Review. Since this site figures prominently in the next phase of fieldwork, the description and the corresponding correlations with various literature sources will be presented below.

Side Scan. Site Surveyed. No contact data.

Remote Viewing. Respondent Ril selected this site by Remote Viewing from his home in Los Angeles, as he answered the first Map Probe questionnaire. The Respondent provided no specifics relating to the site or its contents except that, "it was an important site". ${ }^{12}$

Field Observations. The floor of the harbor was literally strewn with columns and bases, all of Aswan red granite, and all of which were clearly in situ, since the columns all point in one direction and 
many had fallen so as to break into obviously associated fragments. The site itself was on a slight rise or mole, although silt deposition over the centuries had reduced the differential between this area and the surrounding sea floor.

Summary. Site 8 (see Figure 13), was the most visually interesting of the sites located in the harbor proper during the Phase One Fieldwork. From the very first dive in this area, it was clear that this was a major site. Even at this early stage, both Daod and Abbadi (who were present in the dive boat when the divers surfaced and reported; Figure 8) felt that the type and configuration of the ruins corresponded closely with Mark Antony's Timonium. ${ }^{13}$

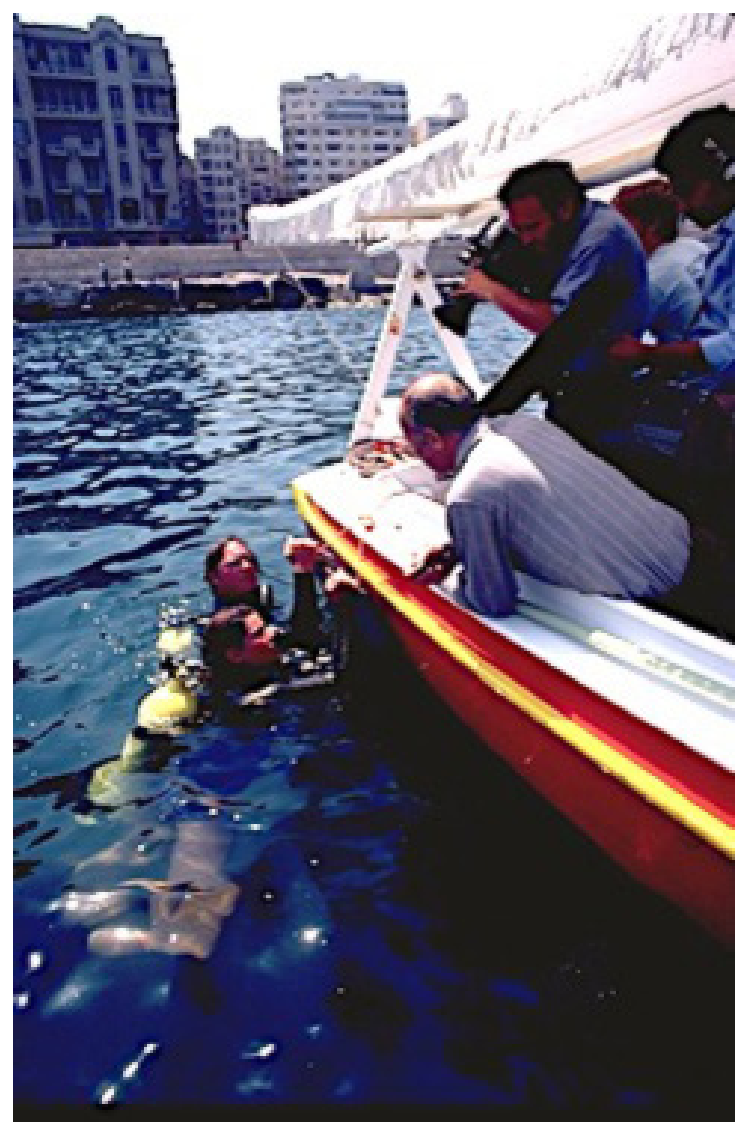

Figure 8. The first author and Kathi Peoples reporting what they have seen to the archaeology team in the boat above them, while the film crew records the exchange. 


\section{Central Harbor, Site 4}

Literature Review. Nothing specific to the site.

Side Scan. Surveyed, no contact data.

Remote Viewing. Volunteered site. Remote Viewing data from $\mathrm{R}_{3}$ while at his Canadian home during the first Map Probe. Site associated with the ancient seawall, which $\mathrm{R}_{3}$ felt extended in antiquity considerably farther out into the sea than is presently the case (see Figure 13 and Figure 28).

Field Observations. Divers found what seemed to be another section of the seawall. The discovery of this site, also approximately 65 meters farther out into the sea from the present-day corniche, provided further support that we had, indeed, located the ancient seawall.

Summary. The decision was made to reexplore this site in Phase Two.

\section{Fort Silsila / Point Lochias, Site 5}

Literature Review. Strabo describes this site by saying: "Lochias with a royal palace upon it" (Strabo, 1949, p. 9). Such word pictures seem clear at a distance when reading them but, when one considers them while on site, one realizes the words are subject to more than one interpretation. Even Fraser seems to get confused when describing the area around Lochias. The problem is further complicated because the eastern peninsula of the harbor which Strabo saw, writing his famous history sometime between $27 \mathrm{BCE}$ and $14 \mathrm{CE}$, was a very different geographic configuration than the one that Saint-Genis saw in the 18th century, or that Mahmoud-Bey saw in the 19th century (Mahmoud-Bey, 1872), ${ }^{14}$ and quite different from the one we see in modern Alexandria today (see Figure 9).

Side Scan. Site surveyed. No contact data.

Remote Viewing. Volunteered Site. Respondent Ril selected Site 5 along Fort Silsila's western flank, and provided a general description of important buildings (see Figure 13 and Figure 26).

Field Observations. The present-day Lochias is a relatively uniform low-lying finger of land whose perimeter is lined with large concrete blocks. It is now virtually concreted over and used as a military installation. In times past it was both much wider and more irregular than it is today (Fraser, 1972, Vol. 1, p. 23). There has also 


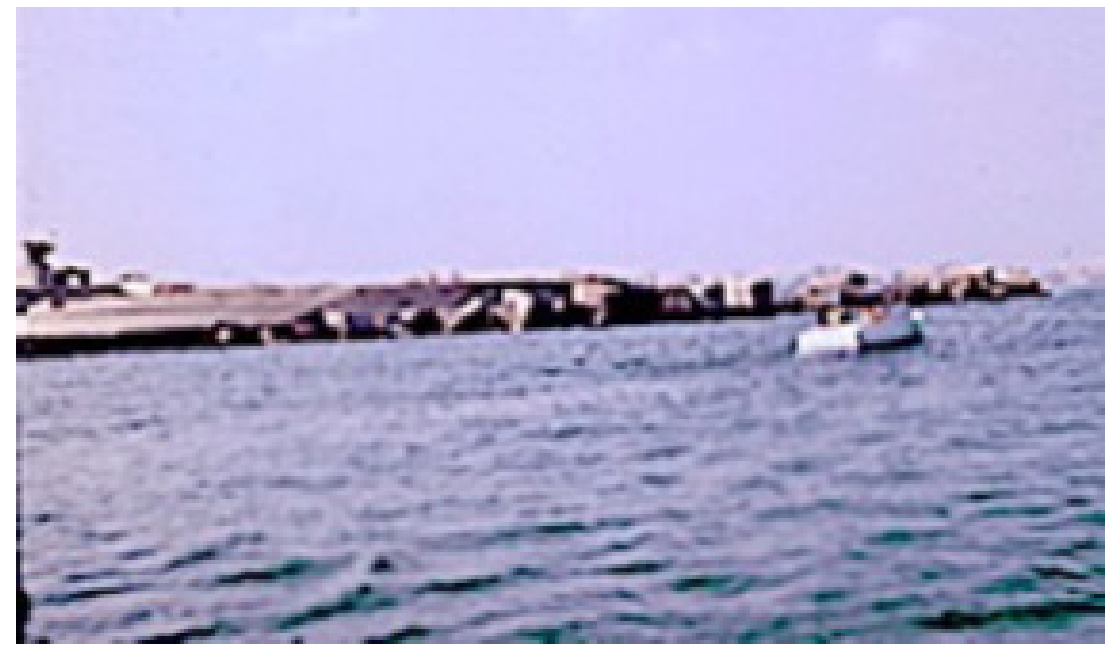

Figure 9. Modern day Lochias.

been considerable subsidence of the land, which only complicates an already-confusing picture. Because of the military security regulations, only two dives, one with one diver and the second the next day with two divers, were permitted, slightly inside the security perimeter in and around Site 5. The first diver reported a 300-square-meter floor of blocks or mosaic approximately 20 centimeters square. A buoy was dropped to facilitate location the next day, but when we made our second dive we encountered what was to prove a continuing source of frustration. Although the buoy was in place, the currents in the bay had shifted and the site was now covered with sediment. Divers reaching down through approximately 20 centimeters of sand could feel the blocks beneath their fingers.

Summary. At the time we were diving security regulations prohibited foreigners from approaching to within closer than 300 meters from the peninsular shoreline (AREN, no date ). ${ }^{15}$ We decided to pursue a waiver of the restriction for the next phase since unbidden Remote Viewing had indicated a site within the restricted area, and diver exploration had already discovered the floor.

\section{Western Side of the Harbor, Sites 1 and 2}

Literature Review. Nothing specific to site.

Side Scan. Area not surveyed. 
Remote Viewing. The sites were selected but little specific descriptive material was provided.

Field Observations. Two divers checked this site, but it proved too dangerous to examine closely. This is the part of the harbor where pleasure and fishing boats are moored, and the boatmen all through the day moved their boats in and out of the harbor directly over where divers would be. They were unfamiliar with diving, had no sense of divers being in the water, and did not appear to recognize the divers' flag. During the short dives, however, we saw what seemed to be remnants of some construction, and we brought up some broken amphorae (see Figure 25), a kind of clay vessel usually a few feet long, used in antiquity to carry cargo like oil or grain.

Summary. This site should not be attempted until some way of protecting the divers from boat props can be set up.

\section{Kait Bey-Pharos, Site 7}

Literature Review. (See Phase Two Fieldwork.) We learned in Alexandria from local archaeologists that four years earlier an archaeologist, Honor Frost, had been permitted to do a very limited number of dives in the harbor and that the Archaeological Society had a copy of the manuscript. The day before we were scheduled to dive at Kait Bey, we read it and found that Frost had dived at Kait Bey. She was not able to spend enough time to do more than say there seemed to be a number of structural antiquities in the area, and she had seen a statue on its side (Frost, 1975). The Frost report described a number of structural antiquities in this area, such as statues. Since the remote viewing data we had already developed significantly matched her report, we made this site a higher priority for further exploration. Much of this matched the remote viewing data we had but had not yet dived on to confirm. Getting this confirmation about the accuracy of the remote viewing made this site a particularly high priority for us.

Side Scan. Site surveyed. Because of the large stone blocks used in the breakwater construction, it was impossible for the sonar survey to differentiate any possible antiquities from the modern breakwater installation (see Figure 10).

Remote Viewing. Two months before coming to Egypt, George McMullen, $R_{3}$, voluntarily provided considerable information concern- 


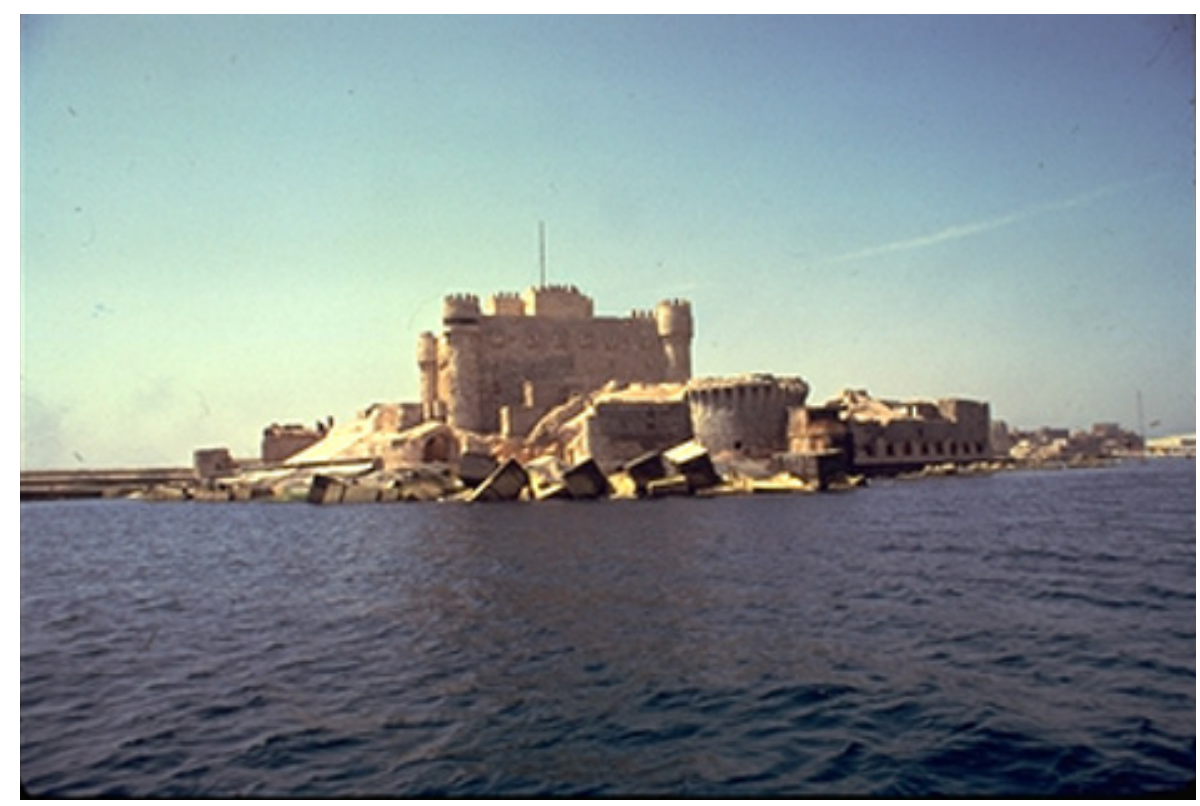

Figure 10. The Kait Bey Fort as seen from the sea entering the harbor. The Pharos Lighthouse site discoveries are clustered around the base of this promontory. Note the modern breakwater blocks.

ing the Kait Bey peninsula and the lighthouse, which he found very interesting. He had drawn it as it may have appeared during several periods of its history. ${ }^{16}$ During late March of 1979 , when Mobius was concentrating on the land phase of its work in Alexandria, McMullen began again to volunteer information about the lighthouse, and that remote viewing data, coupled with descriptions from other viewers, is what convinced us to mount the diving expedition covered in this report.

After the first quick exploratory dive, an on-site session was conducted with McMullen on May 12, 1979. This produced both a detailed drawing of the lighthouse, and the observation that the building was constructed of "red granite". ${ }^{17}$ Of particular interest was his description of "round stone things" (Figure 20), ${ }_{1}^{18}$ which could not be directly correlated with any objects described in ancient sources, nor anything seen on the single dive. This is a good example of a Remote Viewing observation with a low a priori probability. Additionally, things in the first Map Probe also prompted us to search an area approximately 20 meters away. 
Field Observations. In this phase of the fieldwork, because of both the sea state and yet-to-be-resolved permissions, we were able to do have only one diver do one 20-minute dive. On the western side of Kait Bey, the diver reported what seemed likely to be a sewer outlet and, on the eastern side of Kait Bey, what appeared to be building remnants. At the site 20 meters out to sea, he found a wall remnant that may be the channel and dam mentioned by Jondet (Jondet, 1916, pp. 48-50).

Summary. The Remote Viewing data suggested there was much to be discovered at this site, and even that one dive made it obvious that this site would be a high priority for the Phase Two Fieldwork.

\section{Phase One Fieldwork Conclusions}

With the exception of the 8:46 Site, where the commemorative pillar was found, the side scan sonar phase of our survey was generally disappointing. It was equally evident that Remote Viewing proved to be a very efficient search technology. In the absence of side scan contact data, sites that could have taken days or even weeks to find using grid search techniques were found in minutes. Regardless of how sites were located, it was immediately obvious to everyone that the Eastern Harbor held a promise of archaeologically significant finds more than equal to our most auspicious expectations.

\section{PHASE TWO FIELDWORK}

The success of the initial phase of fieldwork led us to conduct a second Map Probe (see Figure 13) using the protocol already described. Questionnaires and a new chart were sent out on October 17, 1979, to nine Respondents. This probe was specifically focused on underwater sites. The charts and questionnaires were all returned on or before October 23, 1979. It was immediately evident that the results were unusually consensual, and overlapped with sites from the first Map Probe (see Figure 5). After analysis, three main areas: Sites 7, 4/8, and $5 / 9$ comprised our first priority. Two additional areas, Sites 10 and 11 (see Figure 5, Figure 13) were targeted for examination as a second order of priority. Sites 1, 2, and 6 made up a third tier of work. 


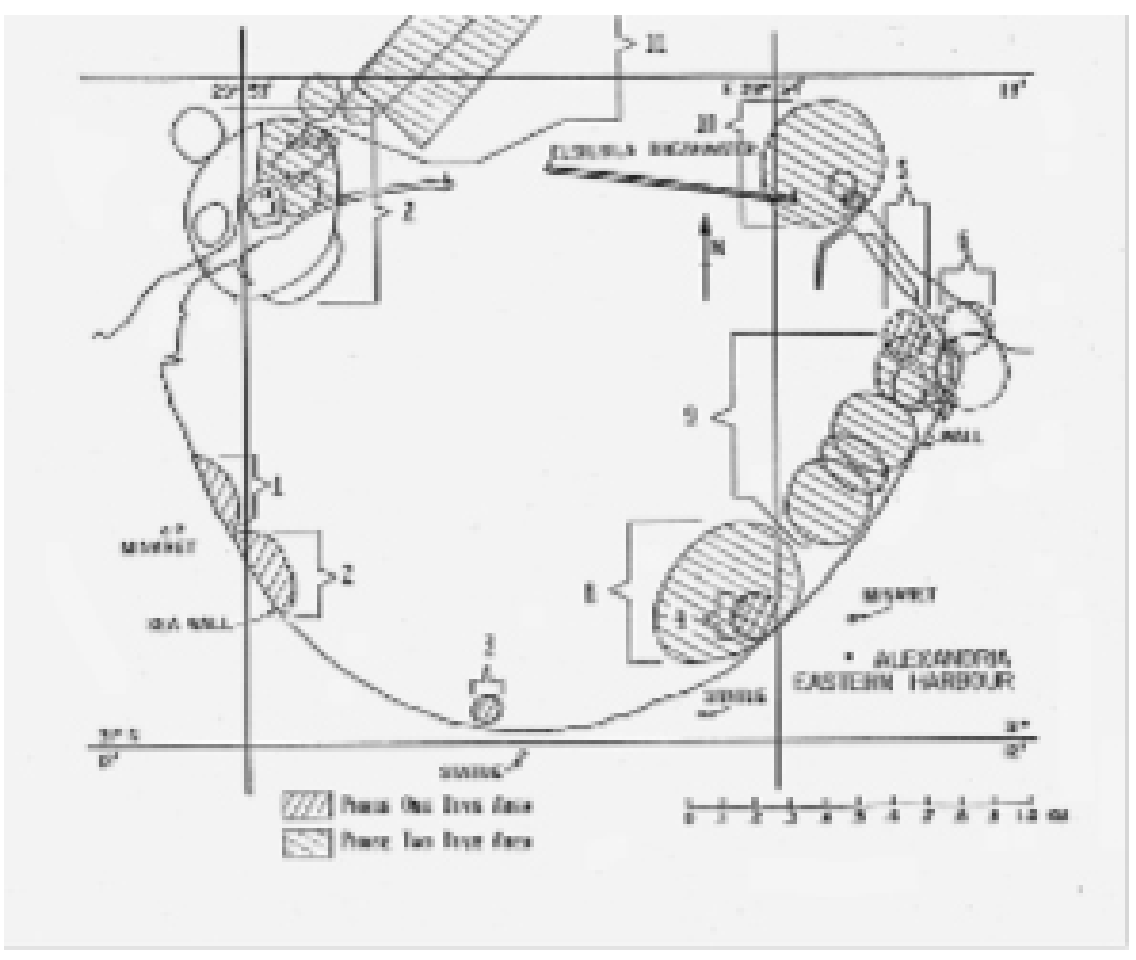

Figure 13. The dive chart was derived from both the first and second probe Composite Maps. Each circle was originally drawn by an individual Remote Viewer. The sites were first surveyed using side scan sonar and then explored by divers during one or both phases of fieldwork.

\section{Pharos, Site 7}

Literature Review. Strabo describes the Lighthouse as ". . . at the extremity of the isle which is a rock washed all around by the sea and has upon it a tower that is admirably constructed of Leucos lithos"-which has sometimes been translated to mean "white marble" (Strabo, 1949, p. 25). This sounds rather simple but it is not. To begin with the area now known as Kait Bey was, in fact, originally two islands with a double arch connecting them that allowed ships to pass between the harbors (Frost, 1975, p. 27). No clear picture of what this looked like survives (see Figure 11, Figure 12). Some authorities feel the lighthouse may have been built not where the Medieval Kait Bey Fort is now located, but upon a small islet, known as Diamond Rock, which now appears to be 


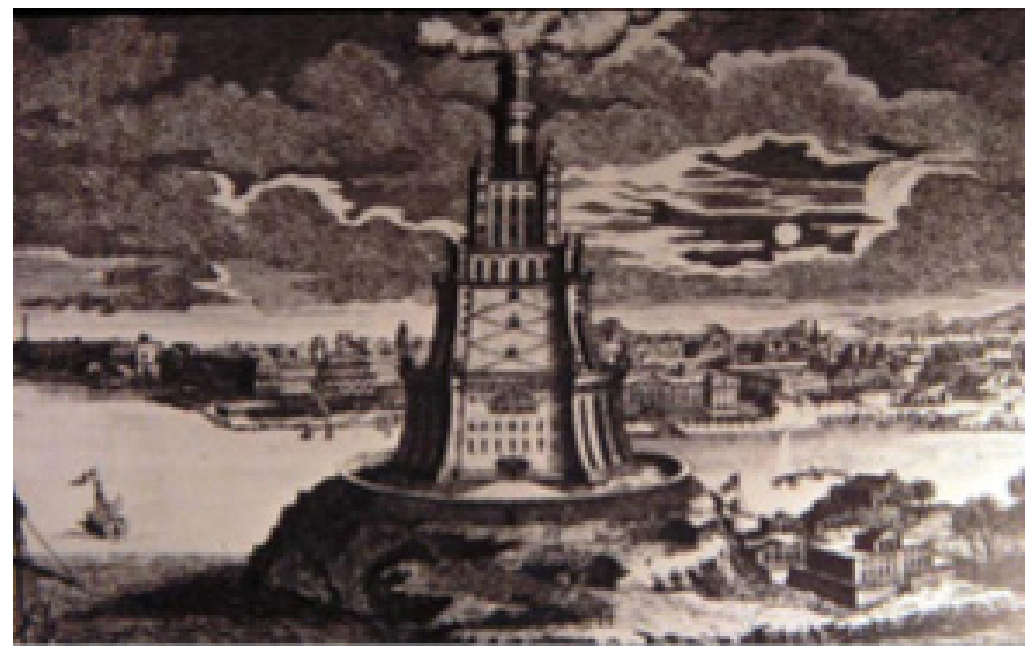

Figure 11. An early depiction of the Lighthouse of Pharos.

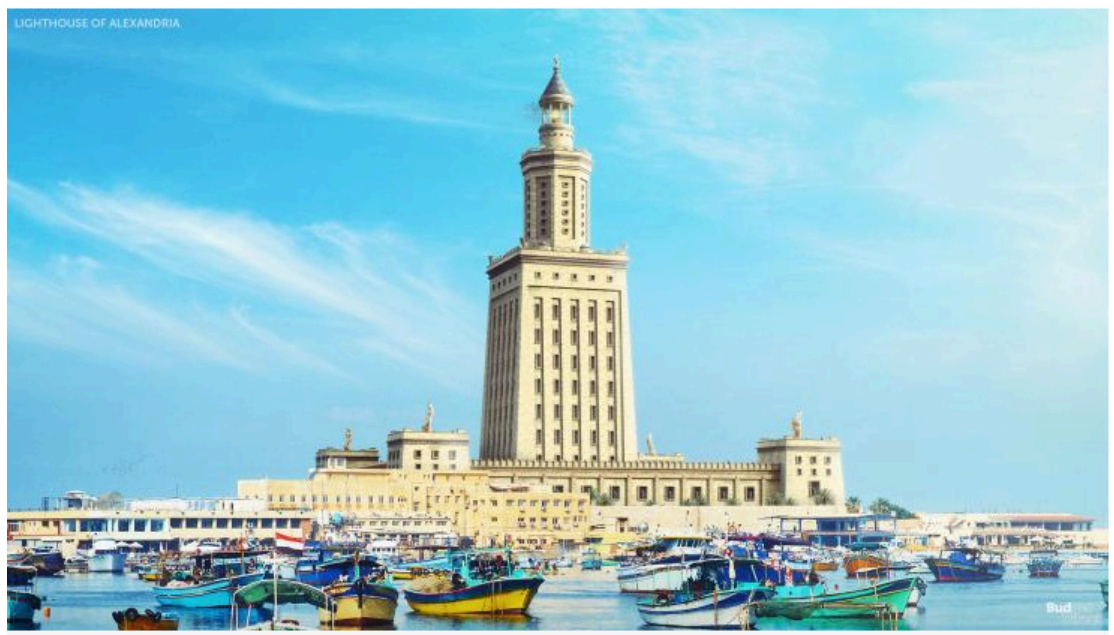

The Lighthouse of Alexandria as it originally stood in 280 B.C. NEOMAM STUDIOS

Figure 12. A modern reconstruction of the Lighthouse of Pharos circa 280 BC.

unrelated to the main mass at the end of the Heptastadium, although as Jondet and Saint-Genis argue, it may once have been connected as part of a larger plateau, sections of which have now sunk (Saint-Genis, 1817, pp. 17-29). Fraser, however, argues against Diamond Rock being the lighthouse site (Fraser, 1972, Vol. 2, p. 44, cf 98). 
Further confusing the issue is the question of what Strabo meant by Leucos lithos. We feel marble would not have been the material chosen during the time of Ptolemy Philadelphus (circa $28 \mathrm{O} \mathrm{BCE}$ ), when the bulk of the lighthouse's construction was carried out (Saint-Genis, 1817, p. 23). Marble is vulnerable to the sea air's corrosive effects and, even more compellingly, there is no proximate source. Historically, marble was sufficiently scarce and expensive that Alexandrian statues often had just their faces carved from it, so it is hard to imagine even the wealthy Ptolemies underwriting the cost of the tons of marble required to even sheath so large a structure. ${ }^{19}$

Frost presents an alternative hypothesis with which we subscribe: The building may have been covered by white or light-colored plaster (Frost, 1975, p. 128). This is certainly within the known parameters of Ptolemaic architecture (Frost, 1975, p. 128). The idea also finds an historical basis in a story told by Lucian, in which Sostratus (who may or may not have been the architect of the lighthouse) (Strabo, 1949, p. 25) wrote a dedication using his own name and then plastered it over, painting on this new surface a second dedication to the king. As the years progressed this superficial plaster covering wore away (one must admire Sostratus' acute sense of timing, revealing, safely after his monarch's death, the dedication to Sostratus which lay beneath; Fraser, 1972, Vol. 1, pp. 19-20).

It is significant that throughout the six dives made by Frost, she ". . saw no white marble though we did find black marble in the sea" (Frost, 1975, p. 128). Frost's initial 1968 UNESCO-sponsored English effort found Aswan granite to be the principal ancient construction material remaining at this underwater site, and this accords well with the granite construction materials found at land sites (Frost, 1975, p. 128). This proved to be the case with our own diving experiences.

The literature suggests that much of the lighthouse fell into the sea beginning in 956 CE when 15 cubits $(\sim 6.4-8.5 \mathrm{~m})$ toppled from the top of the lighthouse (Frost, 1975, p. 128). An earthquake in 1303 appears to have done even worse damage as mentioned in Ibn Battuta's 1326 report (Ibn Battuta, 1929). In 1349, when Ibn Battuta visited again, he found the structure in so ruinous a condition that it was impossible to enter or climb up to the doorway (Ibn Battuta, 1929). Shortly thereafter, it appears to have disappeared entirely from the Alexandrian skyline, 
since eyewitness accounts of the ruins are not found in later reports.

Side Scan. Site surveyed. No useful contacts.

Remote Viewing. The second Map Probe produced a wealth of new material including McMullen's ( $\left.R_{3}\right)$ most complex drawing of Pharos (see Figure 14). ${ }^{20}$ Additionally, the Remote Viewers outlined what seemed to be both temple and lighthouse remains, specifically describing statues, pillars, heads, 'stone beads', and square building stones. ${ }^{21}$ The Lighthouse is considered to be one of the tallest in the ancient world, possibly as much as 122 meters in height. ${ }^{22}$ Notably absent in all of the proffered remote viewing data was any description of the massive remains one would associate with a such a building. It is a classic example of a low a priori probability that is unexpected, and contrary to rational assessment, but nevertheless proves to be correct.

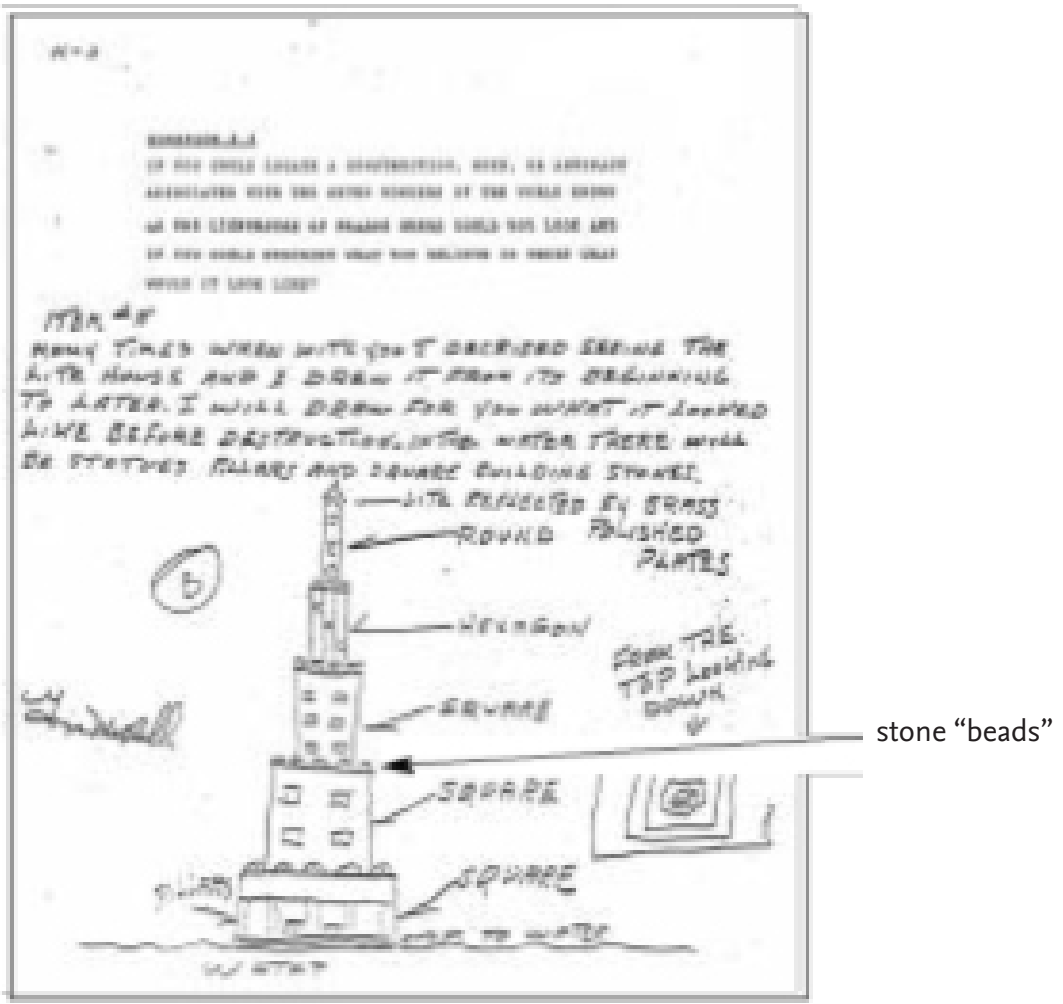

Figure 14. A copy of the original signed drawing of the lighthouse by George McMullen, R3. Note particularly the round stone "beads" ornamenting the first level and the references to the brass mirror. 
Field Observations. Approximately 43 hours of diving time were allocated to the Pharos area during the second phase, with as many as six divers in the water at the same time. The average depth varies between 7 and 10 meters. Orienting ourselves on Kait Bey, we directed our search out from the breakwater in a "pie wedge" pattern, filling in each wedge before moving to the next one. We also directed similar search patterns diverging from finds made by the Frost/UNESCO program. These dives were conducted during October and November, the months generally considered by local divers to be the best "diving window" for these waters. ${ }^{23}$ The water was certainly clearer than it had been during the early summer months, during Phase One fieldwork, but at no time would one have considered conditions ideal, because a voluminous amount of raw sewage outfall came from a sewer pipe just to the west of Kait Bey. On some days, but not others, it also made photography of the sites very difficult, so difficult that we had some drawings made from photographs because the particulate matter in the water was so dense that the photos when printed lost relevant details.

Diving is best carried out prior to 11:00 because the bottom current usually flows west from Kait Bey until then, when it reverses and returns the sewage to the east where the antiquities are clustered. The sewage then became so dense it could be smelled through one's mask underwater. Until, if ever, this sewage issue is resolved, no diver, even when the sewers are not operating, should attempt exploration of this area without a full spectrum of protective injections to the maximum dose for bodyweight. ${ }^{24}$

Further complicating the picture while we were diving, large cement blocks $(\sim 2.5 \mathrm{~m} \times 2.5 \mathrm{~m})$ were brought around by barge and dropped in the antiquities zone to either extend or build up the breakwater. The effect of this construction on antiquities was devastating.

This harbor work did result in one positive effect though. After the blocks were dropped, a heavy storm took place in Alexandria over the next two days, making diving impossible. When we returned to the site, we discovered that the storm had caused a shift in the bottom currents.

More than two meters of silt, composed mostly of sand and broken shells, had shifted, effectively lowering the bottom level. Happily for us, this revealed a host of previously undetected ancient structural remnants.

In general, the most interesting area was a sort of pocket zone 
coming around from Kait Bey, looking east, beginning approximately 12 meters out from shore and extending from the fort around to the Kait Bey breakwater. Here, in spite of turbidity so bad that visibility was reduced to a meter or less, and underwater photography that was intermittently compromised, we found what were clearly the remains of a major structure.

The floor of the sea was almost carpeted with columns, plinths, pediments, blocks (one meter or more square; Figure 15) and other structures. At almost a bisection of the angle created by the Kait Bey fort and the breakwater, a sphinx was found. The sphinx was oriented on its right side and had no head (see Figure 16). It was approximately 2.1 meter long down the back and 1.25 meters high, with a thickness of just under one meter. Kemal Abu al Saadat, who was diving with us, agreed that this was not one of the sphinxes reported by the Frost group.

Slightly farther out and about 20 meters to the east, a very large

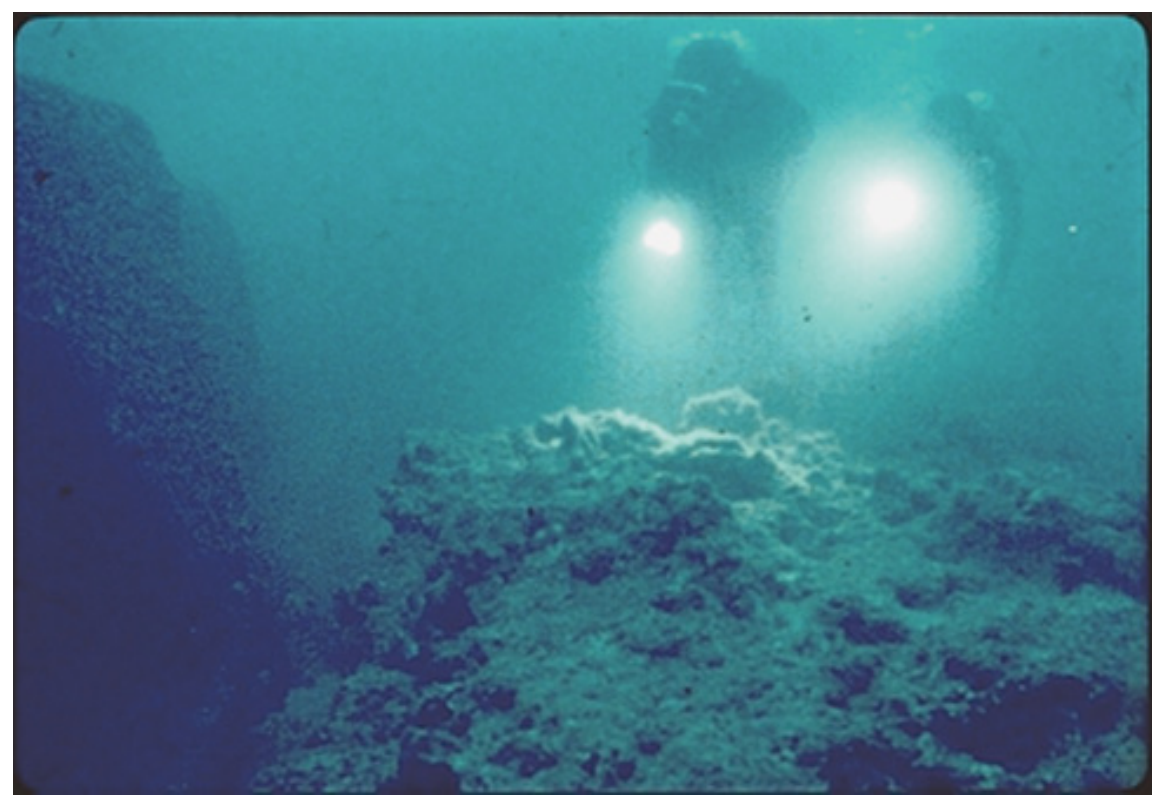

Figure 15. Divers looking at the massive stone blocks that were once the Lighthouse of Pharos. 


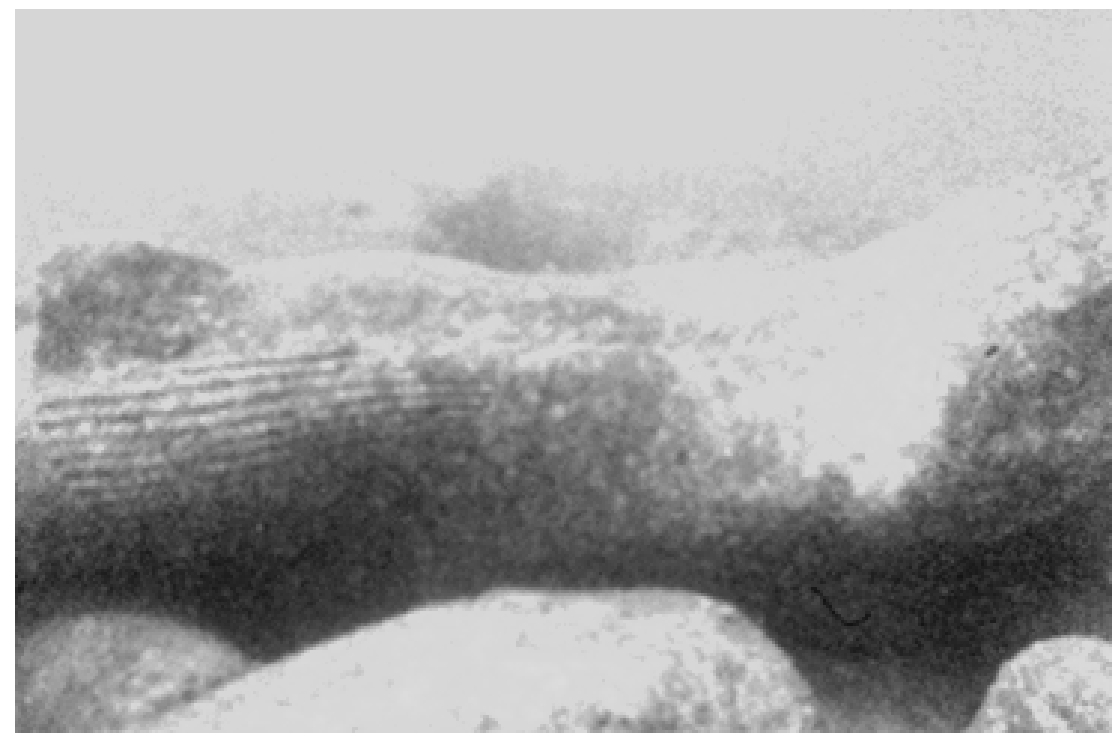

Figure 16. This sphinx was found in a location selected by remote viewing, and was in the condition predicted and described. The photograph (above) was taken during a period when the particulate matter was very dense, and so a drawing (below) was made from a selection of such photographs to give a better sense of what the figure is like.

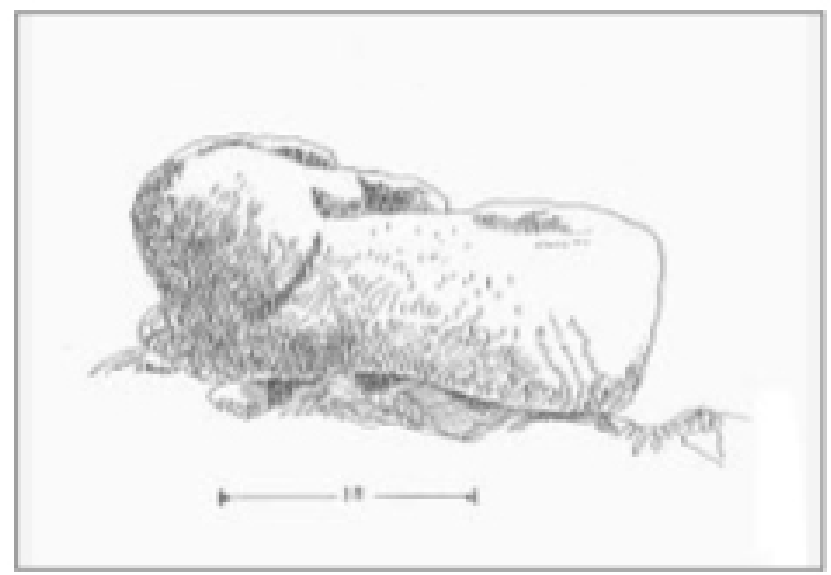

rectangular block was located (see Figure 17). This block was previously undetected. It was about 3.60 meters long, 2.70 meters wide, and 3.60 meters thick. Across what was almost certainly its top were incised a variety of small and large cuts, notches, and recesses (some of which are inside of each other), all of which are obviously human-worked. 


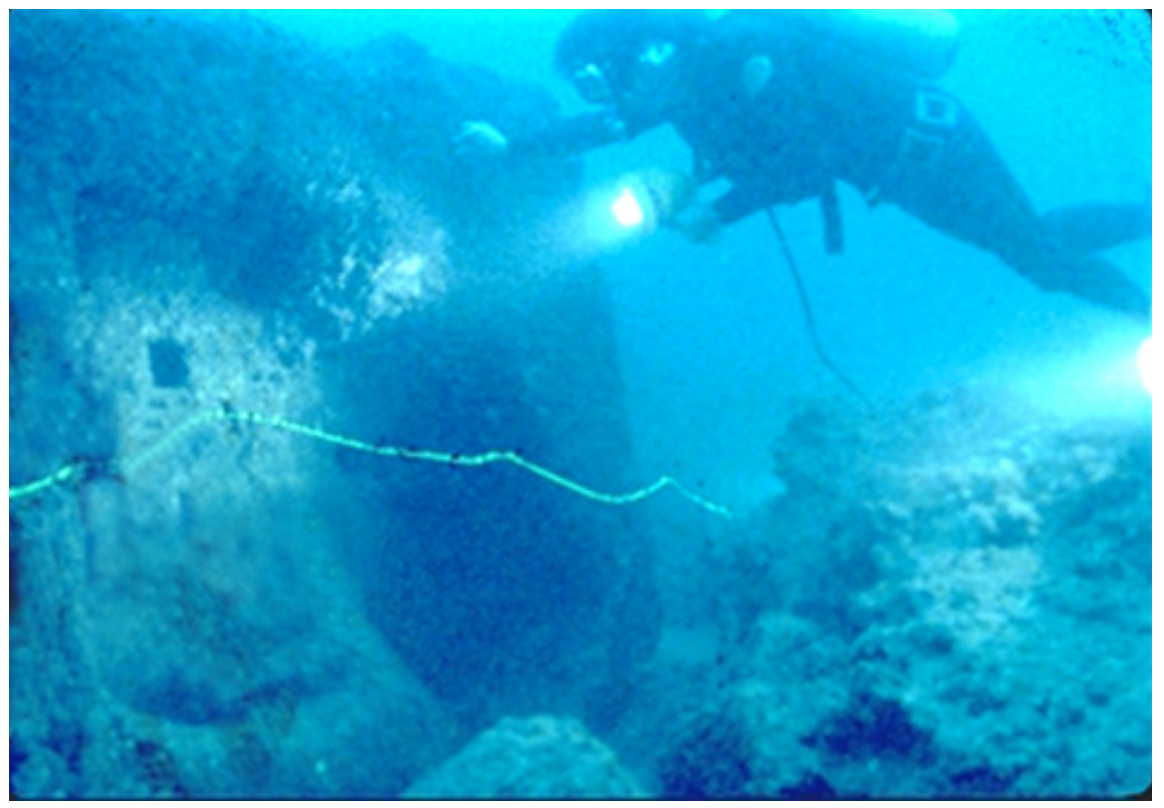

Figure 17. The first photograph ever taken of the Lighthouse of Pharos, one of the seven wonders of the ancient world. The massive scale of the stone blocks makes it clear that the Lighthouse and the surrounding area must have been every bit as impressive as ancient eyewitnesses suggest. Note notches in the base block.

Rodziewicz, when he was shown pictures of this block, provided a possible explanation. He felt that some of the smaller recesses, which were located inside the larger ones, had probably been cut to allow wooden wedges to be inserted to facilitate jamming a lifting ring in place. This allowed the block to be moved. The larger irregular recess was evidently to contain the base of a statue. ${ }^{25}$

Since this recess was over two meters in length it gives some idea of the impressive monolithic nature of the statue. Two other similar large blocks, both reported by Frost, were rediscovered in this area (Frost, 1975, pp. 128-129). Both exhibited similar sockets.

A 4.7-meter long Isis statue also reported by Frost (Frost, 1975, pp. 128-129) was refound. It had what clearly appeared to be a kind of lengthwise rectangular protrusion, possibly used to fasten it to a "female" equivalent in a wall, thus supporting Rodziewicz's explanation (see Figure 18). 


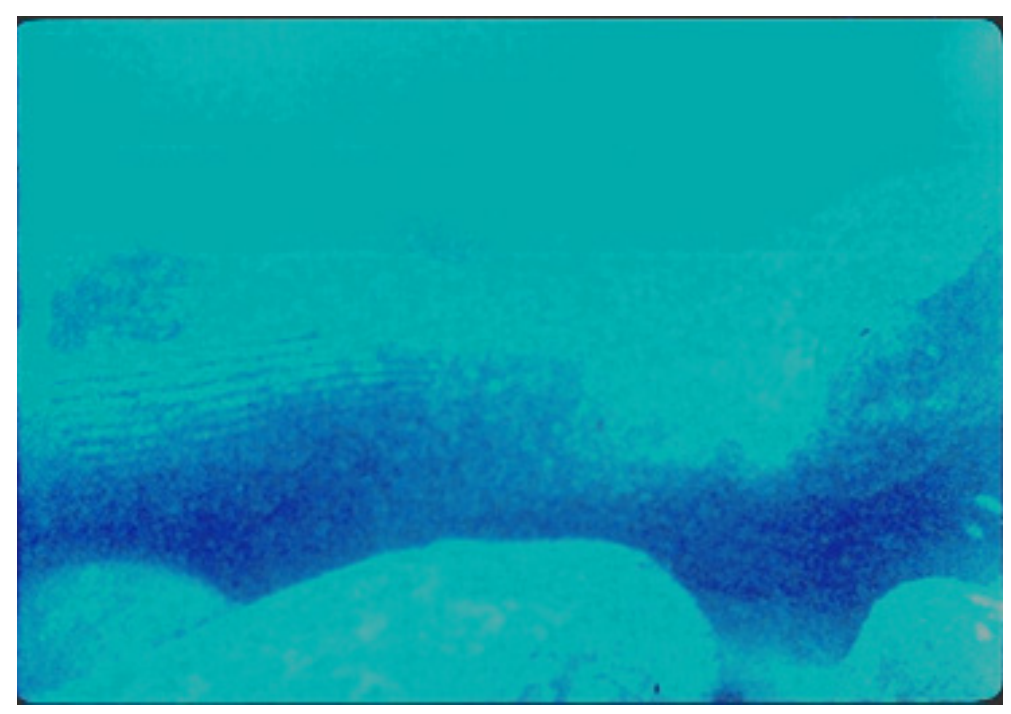

Figure 18. A portion of the Isis statue in the area where the remote viewing data said statues would be found. Note also the heavy particulate pollution in the water. In the color image the folds of the statue's gown can hardly be made out. This situation was not constant but varied day to day.

We did not find the Crown of Isis Hathor which Frost reported (Frost, 1975, pp. 128-129), and we suspect that the hide-and-seek nature of the shifting seafloor accounted for its disappearance. Another crown, however, was located. This one rested about 12 meters offshore. It was 1.8 meters long with Alexandria's trademark blend of Hellenistic and Pharaonic design elements (see Figure 19).

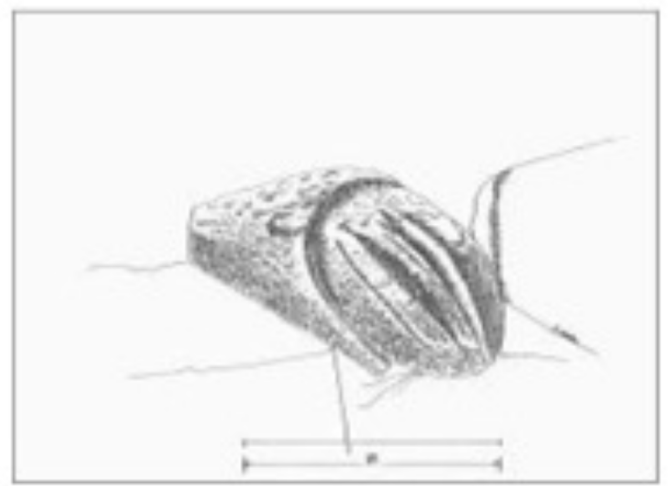

Figure 19. Osirian Crown shows a typical Alexandrian blend of Hellenistic and Pharaonic motifs. It is shown as a drawing because the particulate in the ocean water was so dense it made getting a clear idea of what was found difficult to discern. 
The crown was deemed to be masculine by the Historical/ Archaeological Team. They felt it was probably associated with Osiris, particularly in light of its proximity to Isis.

Close to the crown we located several clusters of the unusual stone "beads" predicted and described by $\mathrm{R}_{3}$ before the first phase of diving had begun. They apparently were exposed when the seafloor dropped, since we had not seen either them or the crown on earlier dives (see Figure 20). The beads were uniformly about 2.6 meters in circumference and, just as in R3's drawing, had holes approximately 20 centimeters across and between 15 and 20 centimeters in depth. They

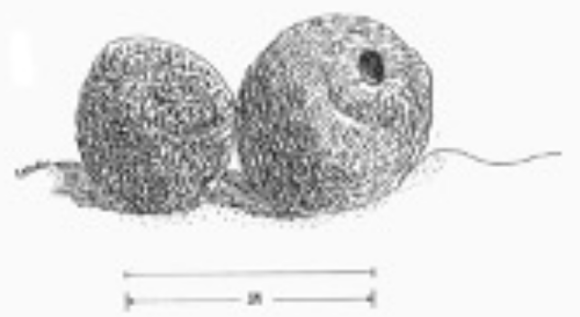
have archaeological significance, but equally they are an example of something predicted by remote viewing, which no one could have anticipated.

Summary. Although there was an impressive amount of structural material at this site, there was not enough to account for a building the size of the lighthouse, which confirmed what the Remote Viewing data had predicted. It is possible that much, indeed conceivably most, of the building did not fall into the sea but was hauled away for use in the construction of other buildings, possibly including the original Kait Bey Fort, and this would explain its absence. Remote Viewing provided an observation about this which we were unable to follow up on, but that we think deserves future consideration: During the course of an on-site Remote Sensing session with Respondent $R_{3}$, he stated that much of the lighthouse material had been reused in the construction of the large mosque near where the fishing fleet is currently moored.

Remote Viewing descriptions of granite-rather than marblealso were confirmed. All the objects we found were formed from Aswan 
granite, except for the sphinx, the crown, and several columns that were of either a gray granite or of syenite. One diver reported a white marble column, but on subsequent dives this could not be relocated.

Fieldwork seemed to confirm another Remote Viewing observation: Since much of the material we found was seemingly religious in nature, the Remote Sensing descriptions concerning a temple that was proximate to the lighthouse seem very reasonable. The sense of the archaeologists was that it was probably associated with Isis Pharia.

The fact that the majority of these remains are clustered in one area, and are evidently in situ, would also seem to argue that the temple site did not fall over into the sea but rather that the land upon which it was situated subsided.

Only further exploration and study will definitively resolve the issue of the missing lighthouse material and allow us to separate what are specifically temple ruins from lighthouse remains.

The absence of statues that might correspond with the bases that both the Mobius and the Frost groups discovered could possibly be attributed to deterioration of marble in the sea, although the Historical/ Archaeological Team felt that something should have remained. Perhaps the statues were removed, possibly even destroyed, during one of the numerous civil confrontations which plague so much of Alexandria's history.

We did not resolve another lighthouse mystery: For centuries there has been a controversy over how the light from the lighthouse was focused-by a lens or a mirror? We can add little except to note that R3 described it as a "polished brass mirror arrangement" (see Figure 9). This seems to us more logical than the lens hypotheses and, although we searched for both, nothing was found. A mirror or lens could, of course, still be beneath the sands. However, we feel-particularly if it was a mirror-that it is far more likely such a valuable mass of metal would have been taken away for recasting.

No one to whom we showed drawings of McMullen's "beads" was able to shed any light as to what they were. Nothing argues against the Remote Viewing data, which suggested they were a decorative element lining the top of one of lighthouse's staged terraces. Indeed, this seems the most probable explanation.

Based on our fieldwork, it seems probable that Fraser is correct, 
and that Diamond Rock was not the site of the lighthouse. We searched around Diamond Rock and found nothing that could possibly be identified as lighthouse remains.

Two final points deserve mention here: It is clear is that this was another instance where the "noise" overwhelmed the signal in the side scan survey. Also, that Remote Viewing provided accurate locations and site reconstruction data that contradicted the common wisdom.

\section{Timonium / Poseidium / Emporium, Site 8}

Literature Review. Strabo says, "Above the artificial harbor lies the theatre; then the Poseidium -an elbow, as it were, projecting from the Emporium, as it is called, and containing a temple of Poseidon. To this elbow of land Antony added a mole projecting still farther, into the middle of a harbor, and on the extremity of it built a royal lodge which he called the Timonium" (Strabo, 1949, p. 39). The site of the Timonium has always exerted a special fascination, since it was here that Antony reputedly fell on his sword; and it was from here that, still living, he was taken to Cleopatra (Plutarch, 1941, pp. 1756-1757; Frost, 1975, pp. 126-129).

But the question of the Timonium's exact location has remained unsettled.

Mahmoud-Bey placed it on his map of the city, along with an accompanying description, putting it about 650 meters from the site he described as the location of the Royal Harbor, on the west flank of Lochias (Mahmoud-Bey, 1872). Further, he stated that it projected about 200 meters from the coast, with an additional 300 meters of masonry construction projecting beyond that (Mahmoud-Bey, 1872). Hogarth, commenting on Saint-Genis' description, felt that what appears to be the remains of quays are probably "... merely the lowest courses of large walls ..." (Fraser, 1972, Vol. 2, p. 21, cf 36). One difficulty is that even in antiquity the city underwent a period of partial desertion in this area. Ammianus Marcellinus indicated that as early as 273 CE much of the core area, including the sites of many buildings near the palaces, had been abandoned (Marcellinus, 1950, pp. 299-301). Approximately 100 years later another writer, Epiphanius, called the area a "desert" (Fraser, 1972, Vol. 1, p. 10). 
Side Scan. Site surveyed. No contact data.

Remote Viewing. Respondent Ril picked a site which he associated with Antony, during the First Map Probe before we left for Alexandria. The Second Probe, which focused on the harbor, produced several overlays on this initial location. Respondent R4 actually used the word Timonium, saying: "There should be parts of columns of the Timonium and one small area at its tip reached by a small hole, this was Antony's small place of his own." ${ }^{\text {26 }}$ Respondent R9 described "a small amphitheater, very small, only room for about 20 people." ${ }^{27}$ Respondent Ri picked the same area, but felt drawn to it initially because he believed that "there were also steps to a small building where Cleopatra walked."28 In analyzing this data, it seemed to us that more than one site was involved, and that this must, collectively, have been an active center during the time of the Ptolemaic city.

Field Observations. As already noted, this site produced substantial finds during our first dives in the late spring of 1979, and became one of our primary targets for diving during the second phase. In all, 30 man-hours were spent diving on this site during the second phase.

Within the harbor, as at Kait Bey, diving is best done in the early morning. A current develops between 11:00 and 11:30, at which time the already turbid water becomes so heavily laden with particulate matter that it seems one is swimming in minestrone soup. Visibility by 13:00 was often reduced to less than a meter. Luckily, there is nowhere near the same amount of sewage as at Pharos, although patches still come in, as well as oil slicks from fishing boats and the usual floating detritus of most modern city harbors anywhere in the world. Strangely though, there is very little litter on the seafloor, found between 6.5 and 8 meters in depth. The bottom is mostly sand and broken shells with some marine growth extending up from the floor.

At the site selected by the Remote Viewers, we found what appeared to be a small peninsula; however we did not find it going out so far as Mahmoud-Bey described. There seemed to be a tapering off at about $80+$ meters out. Also, as previously noted, the differential between the seafloor proper, and the level of the now-underwater peninsula is probably not as great as it once was. Today it averages (acknowledging that this could shift by a meter or more depending on the weather and sea currents) about one meter. 
The first thing that strikes the diver's eye is the large number of broken columns. Although many were in several sections, they are clearly in situ—probably breaking as they fell-because they all point in a common direction, slightly eastward off perpendicular to the present shoreline. All were of the usual red Aswan granite and, collectively, they gave the impression of making up the long side of a building. Not only are they obviously associated but they are of uniform diameter, about one meter. There is also one fairly large (about 15 meters on a side average) "patch" of pottery. Numerous samples of pottery were discovered. Rodziewicz and Daoud made an initial evaluation that they comprised a mix of Roman and Hellenistic. ${ }^{29}$ Their association with the site is, of course, strictly problematic at this stage.

Several bases without columns were discovered, as well as a number of capitals that were approximately one meter across. Unfortunately, the capitals were so corroded that no details could be ascertained except that they appeared to be carved.

At the northern edge of Site 8 , there was a rise. Because we had spent so much time exploring closer in, and because diving was possible only a few hours each day, we were not able to explore this in the detail we would have liked. Two divers swimming over the area both reported that the rise may extend for some distance.

The issue of whether we were seeing the ancient seawall or quays was also settled through the subsequent location of a quay running perpendicular to the wall fragments we began discovering in Phase One Fieldwork. Additional portions of this seawall were discovered to the east of Site 4.

Summary. In light of these discoveries, we believe the ancient shoreline, lined with a brick seawall, ran approximately 65 to 75 meters seaward of the present corniche; the variation probably accounted for by the fact that the ancient harbor was not so regular in appearance as the present day's uniformity.

This site is obviously a series of major constructions. For all that, we found nothing that specifically seemed to us to be the small theater mentioned by the Respondents, but the fact that it was described and is known to have existed is provocative. We also did not discover Mahmoud-Bey's 300 meters of masonry, but it could well be there just under the sand. 
This area is clearly worthy of a much more complete examination using equipment we did not have.

\section{Western Side of the Harbor Including the Base of Fort Silsila / Point Lochias, Sites 5 \& 9}

Literature Review. Strabo says, “. . . one comes on the left to the inner royal palaces, which are continuous with those on Lochias and have groves and numerous lodges painted in various colors" (Strabo, 1949, p. 39; also see Phase One Fieldwork).

Side Scan Sonar. Site surveyed. No contact data.

Remote Viewing. Respondent $\mathrm{R}_{3}$ marked this area, and initiated his response with the flat statement that a palace associated with Cleopatra had once stood at this site..$^{\circ} \mathrm{He}$ also stated that it was at the base of Lochias where Alexander had first sketched out his plans to build the city. ${ }^{31}$ Respondent R4, in the second Map Probe, voluntarily traced out what she felt had been the ancient shoreline and stated also that palaces had been at the base while the Royal Harbor was nearby in the harbor. ${ }^{32}$ There she also described a palace associated with Cleopatra the 7th (the only Cleopatra history remembers): "Cleopatra's palace overlooked the Royal Harbor." ${ }^{32}$ Exactly where she meant the Royal Harbor to be was not clear. A palace was also described by $\mathrm{R} g$ as having been in this area and both she and $R_{3}$ drew pictures which have many similarities (see Figure 21 and Figure 22). Since we had already dived in this area when it was first selected back in the spring of 1979, it was with particular interest that we returned for a second examination.

Field Observations. All caveats about diving conditions for the Timonium/Poseidium apply here as well. There are substantial construction remains in this area but they lie mostly beneath the silt, where they can be felt but not seen. All that could be seen, at least while we were diving, were a few columns and one base similar to the ones found at the Timonium/Poseidium site; the measurements and description are the same. We also found a low rise about 40 meters out from a line obtained by bisecting the angle created where Lochias joins the shoreline. This rise has a kind of amoebic shape and appears to have constructions under the silt within part of the rise. The rise is perhaps 30 meters across at its widest point, although this was hard to estimate with any accuracy because of the silt, the very substantial weed 

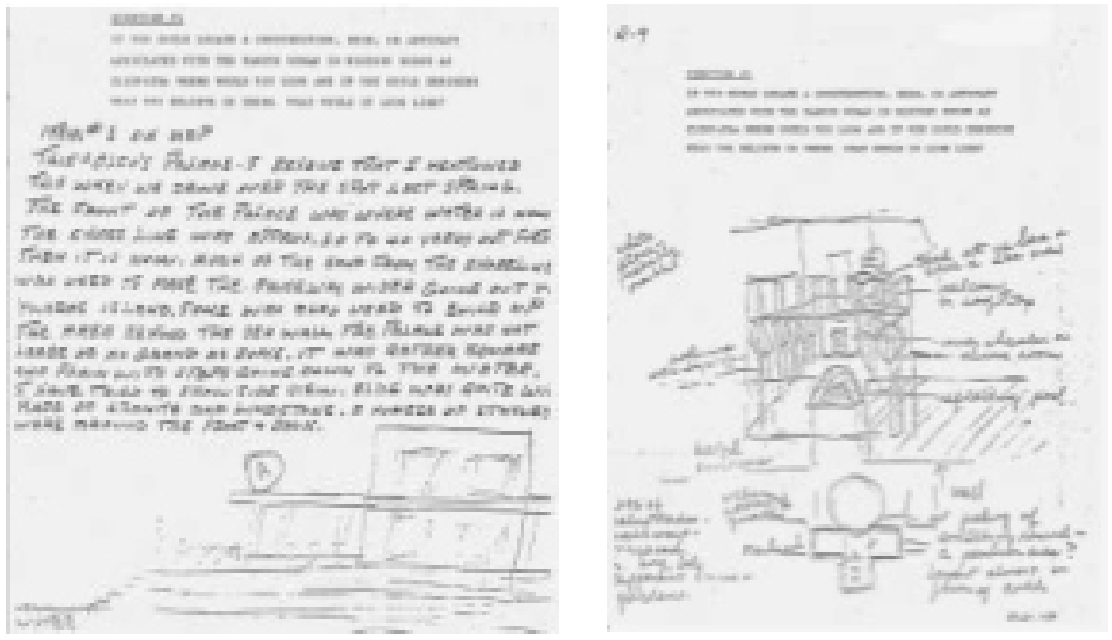

Figure 21 and Figure 22. Similar descriptions independently provided by two Remote Viewers, describing "Cleopatra's Palace." Note the absence of the Pharaonic motifs in each drawing, which are what is usually evoked when most people think of Egypt. A low a priori consensus such as this is considered particularly significant and is given precedence in planning fieldwork.

growth on the seafloor, and the very poor visibility.

Summary. Although this site was visually unrewarding, the fact that material was found, and that so many Respondents, who had been so accurate on so many other issues, picked this one area, leads us to believe that a much more extensive examination should be made. Strabo's description further urges this, since this may well be part of the Royal Complex he describes as the home of the Ptolemies including, presumably, the legendary Cleopatra the 7 th.

In our view the rise we found is the other candidate site for the island of Antirrhodus which lay outside the Royal Harbor.

\section{Tip of Point Lochias, Site 10}

Literature Review. There appear to be no definitive references to this area, other than Strabo's statement that there was a palace on the tip of Lochias (Strabo, 1949, p. 39). This is possibly the palace to which Antony was taken after falling on his sword, the place of the final scene between him and Cleopatra. However, since the peninsula is so 
grossly changed, one can hardly say where the tip that Strabo saw falls in relation to what is present today.

Side Scan. No survey of this area was made.

Remote Viewing. Two Respondents, $\mathrm{R}_{3}$ and $\mathrm{R}_{4}$, each picked a very small and almost exactly overlapping area at the end of the peninsula. Despite the paucity of classical and modern literature source material, and the fact that no side scan sonar was even attempted because the water was too rough, the remote viewing location was so specific that we decided to dive on the site. Viewers $\mathrm{R}_{3}$ and $\mathrm{R}_{4}$ both felt the site had something to do with Cleopatra, although they were not in agreement as to the association, describing it variously as a "tomb" or a "statue" that Cleopatra had built.

Field Observations: Our usual recommendations about diving safety obtained, because there is a sewer with an output equal to that of the Pharos outlet at the eastern base of Lochias whose outfall sweeps around the point (see Figure 9). The average water depth was about 8 meters and the water clarity, when the sewage was not present, was probably the best in the harbor area. The seafloor was also quite clean, with little weed growth and no litter at all. Only one dive, of about 45 minutes, was made here by three divers.

In exactly the area marked by $\mathrm{R}_{3}$ and $\mathrm{R}_{4}$, four large rectangular blocks were located. They appeared to be in situ and were of a size that made it unlikely that they could have been moved. They are not modern. However, because of their angle-they were in a rough line at about a 45-degree angle pointing westward from Lochias' tip-it is possible, although not probable, that they were antiquities dumped here at some later date to form a breakwater. The blocks were all of Aswan granite, and uniform in size and shape; about 3.6 meters long by 1.5 meters wide and 1.65 meters thick. A uniform lip sticking out approximately $10 \mathrm{~cm}$ and about $10 \mathrm{~cm}$ thick went all the way around one end. They reminded one of the platform bases for large statues seen at the Pharos site, but there were no recesses such as were found there. One of the four was broken and we sought to determine whether they were hollow. However, the break, about a meter in from the end, was positioned in such a manner that this could not be determined.

Summary. We could not evaluate the importance of this site, only note that it was situated precisely as located by Remote Viewing. 
Open Sea - North of Kait Bey, Site 11

Literature Review. Nothing specific to the site.

Side Scan Sonar. No survey of this area.

Remote Viewing. Four Respondents chose this area. Two felt that the site was the location of a sunken boat (see Figure 23 for R5's drawing and comments; Arrian, 1942, p. 467). They each drew virtually the same drawing in describing the boat (see Figure 24 for R3's drawing). ${ }^{33} R_{3}$ felt there should also be a statue(s). ${ }^{34} \mathrm{R} 8$ felt the site was related to the ancient lighthouse. ${ }^{35}$

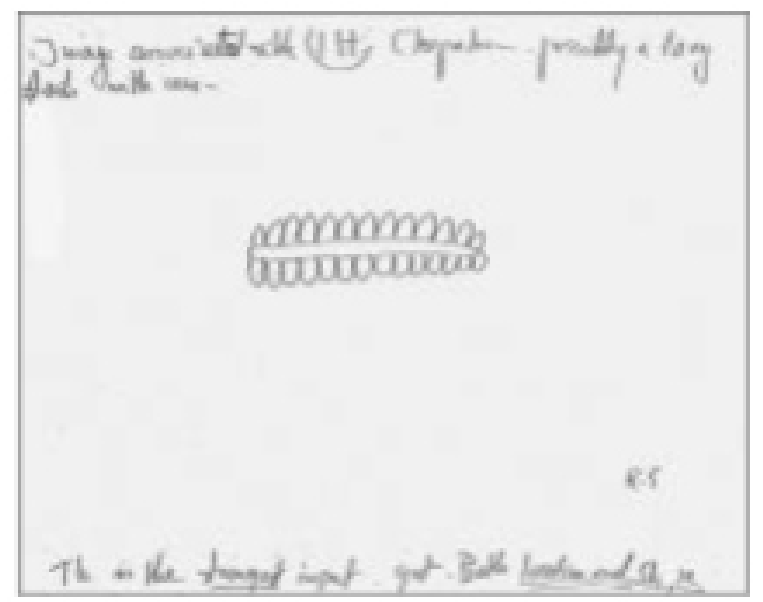

Figure 23. One of two "boat" drawings and descriptions which, along with location, came from Remote Viewing sessions.

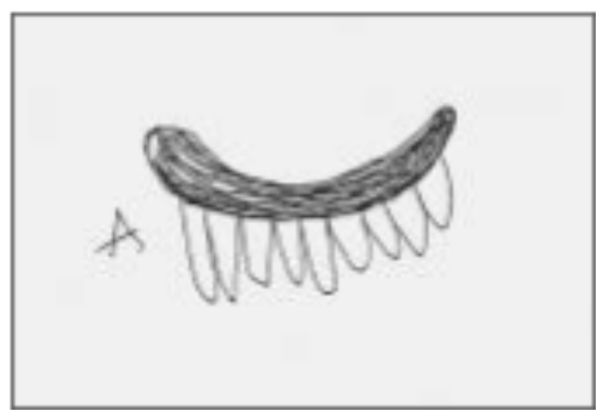

Figure 24. A second viewer, blind to the first, provided essentially the same location, description, and drawing. The repetitive pattern could be oars or amphorae-which were found on site. 
Field Observation. The morning of the dive, the Egyptian diver Saadat, who had been told nothing of the remote viewing perceptions, when asked about the site, said that in 1961, he had been diving at this site and had found a boat with two statues aboard as cargo. He went back to the spot several times but because of the shifting sands nothing could be identified and he had not been able to find either the boat or the statues. We dove on the site and went over the area in detail. We could find neither the boat nor the statues remote viewing had predicted and Saadat in his earlier dives had confirmed. However, there were odd suggestive raised areas beneath the silt, and we found several mostly intact amphorae, commonly used as cargo containers on the cargo boats that trafficked in and out of the harbor in antiquity (see Figure 25).

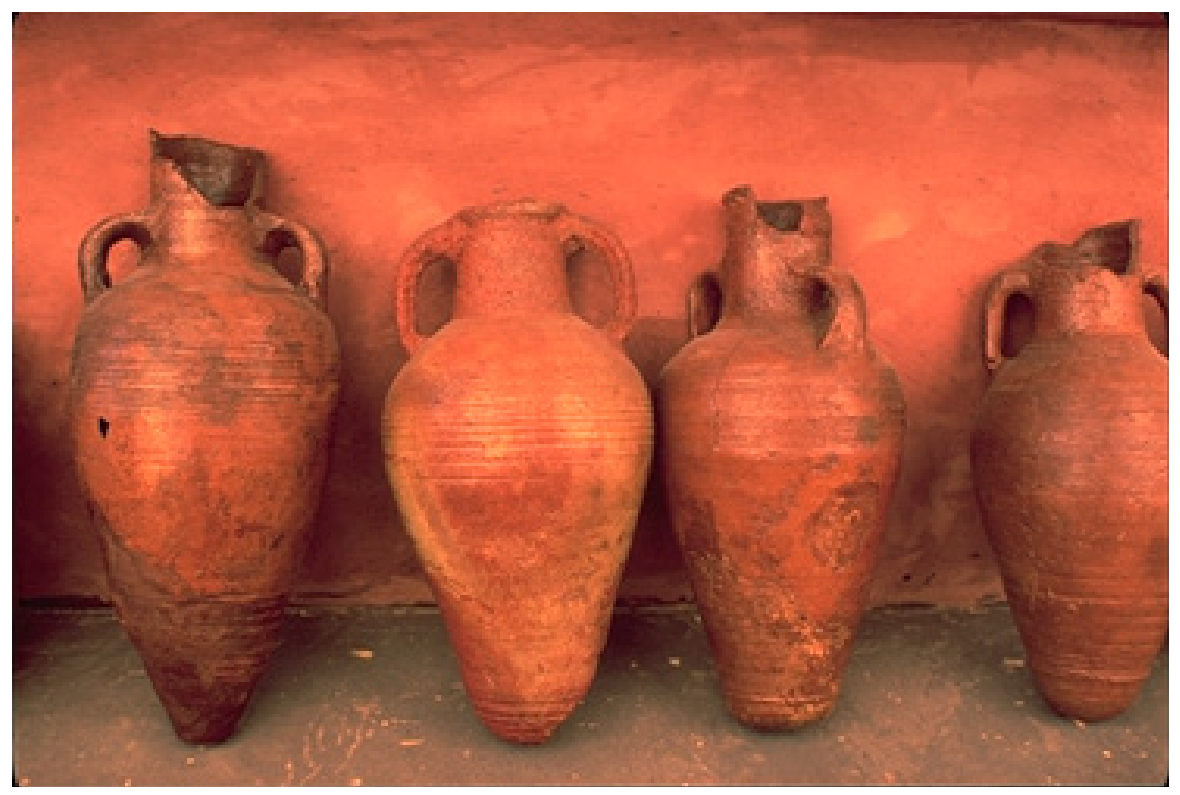

Figure 25. Amphorae used by ships to transport goods found at a site located by Remote Viewing, and described as being associated with a shipwreck.

Summary. Saadat's earlier experience, which confirmed the remote viewing data before we dived, was reconfirmed, and this suggests that this site is worth further exploration. 


\section{East Side of Point Lochias, Site 6}

Literature Review. The same material cited for Site 5 may be relevant.

Side scan. No survey.

Remote Viewing. There has been considerable subsidence at this site and much silting, but it was clear this is what must once have been a palace or impressive administrative structure.

Field Observations. Ruins are visible nearby from the surface on clear sea days. Modern construction has seriously disrupted everything at this site. Two divers reported what seemed to be constructions, which could not be seen, but which could be felt beneath the silt.

Summary. Unless sites like this are explored in the near future, it is likely it will never happen. As at the tip of Lochias, and around Kait Bey, modern harborworks are rapidly precluding future study.

\section{DISCUSSION}

Although this paper presents only a preliminary survey of a complex area, we propose that several independent, yet associated, conclusions can be sustained.

1) Archaeology. First, the locations and reconstructions we made, when added to what was already in the literature, make it clear that the Eastern Harbor and environs are a neglected locale for underwater archaeological examination, and one which holds enormous promise. Except for the bothersome output from the sewers, the diving is technically simple, there is no area requiring decompression allowance, and the rewards are great. We view it as a tragedy that so little has been done in this area, although we recognize that until recently political conditions did not permit foreign divers access to these waters. However, under Dr. Mohammed Hilmy, then the governor who was himself a scholar and for many years professor in the field of Urban Planning at the University of Alexandria, a new science orientation emerged in the governing administration. One manifestation, The Department of Antiquities, has also recently demonstrated some interest in the exploration of the harbor.

The work at the sites located has only begun and, obviously, there is a great deal to discover. It is our hope that the entire Eastern Harbor 
area can be declared a protected underwater archaeological park, and a sustained multi-year program, similar to that being carried out by the University of Warsaw at Kom El Dikka, funded and begun.

The fieldwork also calls into question some ancient sources, notably Strabo. The complexity of the finds at what we have designated Site 8 suggests that his description of the Eastern Harbor in 24 BCE may be skewed. The things he says were there seem to be there, but not quite where he places them.

2) Comparison of Electronic and Remote Sensing. It is obvious that Remote Viewing was more productive than side scan as a search approach, in this setting. Even if the sea conditions had allowed for a more successful side scan survey, doing it would have taken weeks or even months. That is another difference between electronic remote sensing and remote viewing. In remote viewing there is no search. One goes to the selected location and finds what has been described or one does not.

With remote viewing guidance, it never took more than a few minutes to locate the site. There are many benefits: a) It is cheaper to search in this manner. b) Even if electronic remote sensing is used, its employment can be much more focused (if Remote Viewing fails one can always fall back on standard electronic search protocols). c) In underwater archaeology, where time is always an issue, it is more efficient to use Remote Sensing. d) The "worst" case scenario using Remote Viewing, is the "best" case scenario to be obtained using electronic sensing alone. This does not mean we are arguing for the abandonment of electronic sensing, quite the contrary. Our view is that these two approaches are best employed together in both a complementary and comparative manner.

3) Remote Viewing Accuracy. It is not clear that the various types of Remote Viewing data should all be given equal weight, and this is the most pressing problem facing this technology. The location data worked very well. The descriptive material was also impressively accurate. The Stone "beads," with their small holes, are a good example. The part that is not clear yet is whether the analytical material, i.e., that this site was associated with Mark Antony, will prove to be equally correct. Our initial conclusion is that it will not. Remote Viewing has not proven very useful for analysis or subjective judgments, i.e., how 
many times does a person have to be in a building to be associated with it? But we lack the relevant information to be clear about this. Only further experimentation will answer the question.

4) Issues of Blindedness. A problem whose answer was known neither by researcher nor Remote Viewer, but which was known by someone or some literature source, would be double-blind; a question whose answer was totally unknown, to be revealed only through fieldwork, would be considered triple-blind. The Eastern Harbor experiment included sites where varying degrees of blindness obtained. Certain locations, most notably the Lighthouse of Pharos, were known in at least a general sense. Others, such as the site on the flank of Fort Silsila / Point Lochias, were not.

The Respondents probably did not have access to the rare or obscure books or manuscripts which contain the information cited in the Literature Review sections of this paper, and did not know they were going to be asked about these subjects, until they were. But the possibility exists that some general knowledge or just good luck could account for some of the Remote Viewer's success.

It is also true that even where the general location was known there were still opportunities for triple-blind work in the location and description of previous unknown material within the site. The experiment as a whole illustrates how applied Remote Viewing experiments differ from laboratory research. In an applied experiment, success ultimately turns on whether the site being sought is found or not, and whether the reconstructive material is accurate. This is in contrast to laboratory research where evaluations of accuracy ultimately are statistical.

5) Final Evaluation: We believe the most conservatively accurate assessment of this survey project would be that the literature review was more useful than side scan sonar data, and remote viewingparticularly in locational terms-was more valuable than either. The mechanism of remote viewing may not be well understood but, operationally, using this methodology clearly produced significant original and supplementary locational guidance as well as providing accurate predictive reconstructive information, all confirmed by diving fieldwork and expert evaluation. As hypothesized, the use of all three information sources working in concert produced optimal results. 


\section{POSTSCRIPT}

There are two other aspects to this research that are significant and need to be included in this report: Reconfirmation of the expedition's success, and the media. I have described both of these issues at length in my book The Alexandria Project, but want to just touch on them here.

\section{Reconfirmation}

After our work was completed, Professor Mieczyslaw Rodziewicz, generally regarded as the most knowledgeable working archaeologist on Alexandrine archaeology, made his view clear in a filmed interview. He said: "As an archaeologist [with 20 years experience working in Alexandria], I would say the discoveries are of the highest importance, because they extend the plan of the ancient city. I would classify this as much more important than the discovery of the tomb of Alexander the Great, because this extends our general knowledge of one of the biggest cities of the ancient world." ${ }^{36}$

In the Fall of 1995, a French-Egyptian archaeological team involving some of the Egyptian archaeologists who had worked with Mobius in 1979-1980, and who knew all of our findings, announced the results of a much longer survey they had conducted. Every site located and described by the remote viewers was confirmed, as this map makes clear (Figure 26).

\section{Media}

On January 11,1980 , we presented this paper at the annual meetings of the Society for Underwater Archaeology in Albuquerque, New Mexico. A reporter was in the audience, and he filed a story, mentioning that one of the sites found had been the palace of Cleopatra. The reaction was like calling down lightning. The story seemed to move almost instantly across the wires, starting a cascade of calls. In retrospect, it seems appallingly naïve that we didn't anticipate this. But we didn't.

The three major broadcast networks at the time ran the footage they had urgently requested for their evening world news the following day. The next day I stepped outside in the early morning, hair awry, clad in nothing but a galabeya - a kind of long Egyptian nightshirt-to get my morning paper and found, as the door clicked firmly behind me 


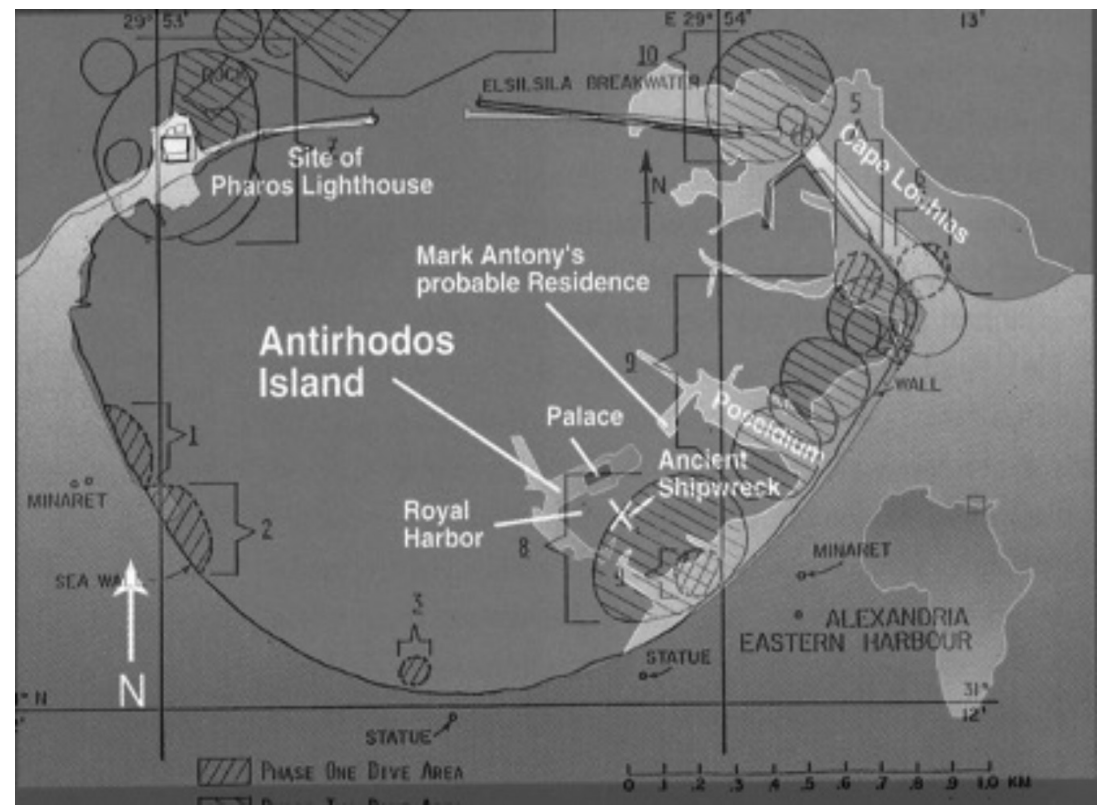

Figure 26. The original Mobius remote viewing master map overlaying the 1995 French-Egyptian team chart reporting their findings.

trapping me in place, three news crews in my driveway, their cameras pointed at me like big game guns about to fire.

I soon learned that newspapers all over the world had put the story on their front pages. Here's The Washington Post's front page first story (Figure 27).

A year later I presented a second paper from the Alexandria expedition, this time at an archaeology conference held at the De Young Museum in San Francisco, a paper recently published in this JSE journal (Schwartz, 2019). It described the location and description of a previously unknown Byzantine site in the buried city of Marea in Egypt, about 40 kilometers into the desert outside of Alexandria, and the day after it was presented the whole media madness started again. The Marea paper, like this paper, used the same consensus protocol, and like this paper compared electronic remote sensing and remote viewing (Schwartz et al., 2019). As with this paper, it reported that electronic remote sensing had failed where remote viewing had succeeded.

In the years since the work reported in this paper, I have carried 


\title{
Cleopatra's Palace Believed Discovered
}

\begin{abstract}
$\ln =90 y$ 13, 1000
What a team of underwater archeologists suspect may be the ruins of the palaces of Cleopatra and Marc Antony have been found in 20 feet of water in the eastern harbor of the ancient city of Alexandria in Egypt.

The discovery of large stone columns embedded in the mud of Alexandria barbor by divers has prompted them to say they discovered the ruins of the two places. The divers did not return any of the columns to land. Instead, they photographed the columns and presented the photographic evidence at the eighth annual Underwater Archeological Conference in Albuquerque Friday.

Bruno Crespi, a spokesman for Mobius, that besides the stone columns divers had found the remains of marble and granite statues in the harbor at a different location that he says be foels came from an
\end{abstract}

Figure 27. Front page of The Washington Post, January 13, 1980.

out a number of other archaeological projects all over the world using remote viewing, and comparing that information with data developed through electronic remote sensing (Schwartz, 2019; Schwartz \& De Mattei, 2020). In every case remote viewing proved successful while electronic remote sensing was not. And because it was all filmed, recorded, and under the direct observation of recognized historical and archaeological specialists, none of this work has been attacked by the usual deniers of nonlocal consciousness research, and I think that is an important point.

\section{ACKNOWLEDGMENTS}

We wish to acknowledge and thank The Honorable Dr. Mohamed Fouad Hilmy, Governor of Alexandria, under whose personal auspices this research was carried out, for his many kindnesses. We thank also Dr. Youseff Garianhi, Director of the Greco-Roman Museum, and his staff, for their assistance in the literary research that went into this paper. Our thanks also goes to Rear Admiral Aly, AREN, Commander of Egyptian Naval Forces in Alexandria, for making it possible for the commando dive team in his command to work with us. Captain Mosehn El-Gohary, AREN (Ret.), and Captain Shafik Wahden, AREN (Ret.), principals of the Red Sea Divers Service, we wish to thank for their almost miraculous 
ability to locate equipment we needed. Finally, and most particularly, we thank John and Pamela Leuthold, Mrs. Margaret Pereria, Trammell Crow, and Gordon McLendon without whose generous financial support the project could not have been undertaken.

\section{NOTES}

1 Fraser's three-volume work (Fraser, 1972) is unquestionably the finest overall modern source, although there is no formal bibliography as such. References are included in the copious notes, often in abbreviations which may be cryptic to those not thoroughly familiar with the source literature on Alexandria. One can do no better in seeking to understand trade during the Ptolemaic period, and to a slight extent later, than to review Fraser's Volume I, Chapter 4.

2 Reports of underwater ruins abound, but perhaps the best are those contained in Description de l'Égypte (Commission des sciences et arts d'Égypte, 1809-1922), which was prepared by researchers accompanying Napoleon during his incursions into Egypt. These men wrote with a standard of observation which at least anticipates the modern day, and they had the benefit of seeing Alexandria before the Khedival and later constructions began. In Description de 'Égypte, see especially Saint-Genis in Antiquities, Vol. 2 (1817), Chapter 26, pp. 1-95, particularly Section Premiere, Partie Maritime, pp. 12-14; also appendices, pp. 1-12, also Gratien le Père in État Moderne, Vol. 2, 2 parts, pp. 262-324.

3 Alexandria's shoreline has actually been in a state of man-made flux since the city's founding-the causeway from Heptastadium to Pharos Island being an example. But the late 19th century saw the major changes. In the 2oth century the shoreline itself-if not the structures on it-has been relatively stable.

4 We were never able to locate any written record of this work, although Frost references its occurrence, and several of our consultants remember it taking place, although not exactly what happened; it apparently was very informal.

5 Although very limited in scope, Frost's work (1975) was the only prior modern survey report of the Eastern Harbor we were able to discover.

${ }^{6}$ Eight Egyptian citizens who had lived most or all of their lives along 
the seafront were interviewed; their median age was 63. They reported that within their lifetime, to the east of Lochias, and particularly beyond the Chatby area, the city had been largely vacant. Governor Hilmy reports that, "Alexandria for several decades has had a chronic overpopulation problem which has fueled an extremely active building program... . Much that was vacant and even the former gardens of villas have had to be built upon" (personal communications, May, 1979).

7 The construction of this shoreline has caused enormous problems in establishing any stratigraphic context on finds near the shore (see Fraser, 1972, Vol. 2, p. 13, note 31).

8 Harold Edgerton, personal communication, May 8, 1979.

9 Norman Emerson, Department Anthropology, University of Toronto, interview on November 14, 1974. Emerson began reporting on his work using Remote Viewing in 1974 and continued until his death in 1978.

${ }^{10}$ Although we find no research specifically designed to evaluate the accuracy of volunteered vs. elicited data, numerous researchers mentioned the subjective conclusion that "volunteered response material which the sensitive himself feels is worthy of mention, seems often to be more accurate than subject areas predetermined by the researcher."

${ }^{11}$ Diver report, May 13, 1979.

${ }^{12}$ Remote Viewing transcript, R11, February 16, 1979.

${ }^{13}$ Interview with Mostafa el Abbadi, Department of Archaeology, University of Alexandria, and Daoud Abou Daoud, Department of Archaeology, University of Alexandria, and Secretary of the Alexandria Society for Archaeology, on site on May 14, 1979.

${ }^{14}$ Mahmoud-Bey, known casually as "El Faliki" (the Engineer), was actually an astronomer in the Khedival government. Although he is a very controversial figure, his midnineteenth-century excavation work was one of the first systematic archaeological explorations of Alexandria-done at a time when much that was ancient still remained relatively in situ.

${ }^{15}$ It is perhaps worth noting that Egyptian security personnel accompanied us at all times during our survey of the Eastern Harbor.

${ }^{16}$ Remote Viewing transcript, Respondent R3, May 12, 1979. 
${ }_{17}$ Remote Viewing transcript, Respondent R3, May 12, 1979, and drawing (Figure 20).

${ }^{18}$ At the time this paper was prepared, the identification of these stone "beads" still remained a mystery.

19 Interview with Youssef El-Gheriani, Director of the Greco-Roman Museum of Alexandria, May 7, 1979.

${ }^{20}$ Remote Viewing transcript, Respondent R3, October 17, 1979.

${ }^{21}$ Composite Analysis Map, Probe II, October 17, 1979.

${ }^{22}$ Strangely, given its fame, there is no clear source from antiquity which provides the dimensions of the lighthouse, nor more than generalities concerning its appearance.

${ }^{23}$ Interview with Captain Moshen El Gohary, AREN (Ret.), Director Red Sea Divers Service, April 9, 1979. Captain Gohary proved to be the best source by far concerning diving information in Alexandrian waters.

${ }^{24}$ Mobius Medical Advisor Donald Zimmerman, M.D., M.E.E. recommended injections of gamma globulin $B$, tetanus, typhus, and cholera, as minimum protection for diving in the hazardous littoral waters of Alexandria.

25 Interview with M. Rodziewicz, November, 17, 1979.

${ }^{26}$ Remote Viewing transcript, Respondent R4, response to Map Probe II, October 17, 1979.

${ }^{27}$ Remote Viewing transcript, Respondent R9, response to Map Probe II, October 17, 1979.

${ }^{28}$ Remote Viewing transcript, Respondent $\mathrm{R} \mathfrak{l}$, response to Map Probe II, October 17, 1979.

29 Interviews with Rodziewicz and Daoud, November 21, 1979.

${ }^{30}$ On-site Respondent interview in April 1979. Map Probe II, October 17, 1979.

${ }^{31}$ On-site Respondent comment, R3, volunteered April 8, 1979.

${ }^{32}$ Remote Viewing transcript, R4. Map Probe II, October 17, 1979.

${ }_{33}$ Remote Viewing transcript, Respondent R5, response to Map Probe II, October 17, 1979.

${ }^{34}$ Remote Viewing transcript, Respondent $\mathrm{R}_{3}$, response to Map Probe II, October 17, 1979.

35 Remote Viewing transcript, Respondent R8, response to Map Probe II, October 17, 1979.

${ }^{36}$ Filmed interview with M. Rodziewicz, October 16, 1980. 


\section{REFERENCES}

AREN. (no date). Memorandum on security regulations relating to Fort Silsila. Navy of the Arab Republic of Egypt (AREN), Mohamed Aly, Commander, Naval Forces of Alexandria.

Arrian. (1942). The annabis of Alexander. In F. R. B. Godolphin (Ed.), The Greek historians: The complete and unabridged historical works of Herodotus, Thucydides, Xenophon, and Arrian (Trans. E. J. Chinnock; Vol. 2). Random House.

Commission des sciences et arts d'Égypte. (1809-1922). Description de l'Égypte. Imprimerie impériale.

Emerson, N. (1975, September-October). Psychic archaeology. Psychic, 23-35.

Fakharani, F. (1974). The tomb of Alexander the Great. University of Alexandria (unpublished).

Fraser, P. M. (1972). Ptolemaic Alexandria. Oxford University Press.

Frost, H. (1975, March and September). The Pharos site, Alexandria, Egypt. The International Journal of Nautical Archaeology and Underwater Exploration, 4, 126-129.

Gorringe, H. H. (1882). Egyptian obelisks. Self-published.

Ibn Battuta. (1929). Travels in Asia and Africa 1325-1359 (Trans. H. A. R. Gibb).

Jondet, G. (1916). Les ports submerged de l'ancienne Ile de Pharos [Monograph 29]. Mem. Institut Egyptien.

Jondet, G. (1922). Monograph 2. Mem. Societe Sultan de Georg.

Mahmoud-Bey (“El Falaki”). (1872). Memoire sur L'antique Alexandrie. Luno.

Marcellinus, A. (1950). The history of [surviving books] (Trans. J. C. Rolfe; Vol. 2). Harvard University Press.

Plutarch (1941). The lives of the noble Grecians and Romans (Trans. J. Amyot [Greek to French], Trans. T. North [French to English in 1579], 8 volumes). Heritage Press. (Text prepared by R. Baughman)

Puthoff, H. E. \& Targ, R. (1976, March). A perceptual channel for information transfer over kilometer distances: Historical perspective and recent research. Proceedings of the Institute for Electrical and Electronic Engineering, 64(3), 329-354.

Saint-Genis, M. (1817). Description des antiquités d'Alexandrie et ses environmens. In Description de L'Égypte(Vol. 2, Chapter 26, pp. 1-95). Imprimerie Impériale.

Schwartz, S. A. (no date). Psychometrics and settlement patterns: Field tests on two Iroquoian sites (unpublished paper).

Schwartz, S. (1978a). Two application-oriented experiments in remote viewing: One testing the ELF hypothesis, the other a protocol for associational Remote Viewing. Mobius Report No. 5, and Proceedings, Parapsychological Association Annual Meeting, 1978.

Schwartz, S. A. (1978b). The secret vaults of time. Nemoseen Media. 
Schwartz, S. (1979, January). Project Deep Quest, a prototype experiment in the application of intuitively derived data in marine archaeology. Mobius Report No. 4. (Originally an invited address to the American Society for Psychical Research, January 1979).

Schwartz, S. (2017). Remote viewing. Psi Encyclopedia (updated March 2021). https://psi-encyclopedia.spr.ac.uk/articles/remote-viewing

Schwartz, S. (2019). The location and reconstruction of a Byzantine structure in Marea, Egypt, including a comparison of electronic remote sensing and remote viewing. Journal of Scientific Exploration, 33(3), 451-480.

https://journalofscientificexploration.org/index.php/jse/article/view/1479

Schwartz, S. A., \& De Mattei, R. J. (2020). The discovery of an American brig: Fieldwork involving applied Remote Viewing including a comparison with electronic remote sensing. Journal of Scientific Exploration, 34(1), 62-92. https://journalofscientificexploration.org/index.php/jse/article/view/1481

Schwartz, S. A., De Mattei, R. J., \& Smith, R. C. (2019). The Caravel project. Zeitschrift für Anomalistik, 19, 113-139. http://dx.doi.org/10.23793/zfa.2019.113

Strabo. (1949). The geography of Strabo (Trans. H. L. Jones; Vol. 8). Harvard University Press; Heinemann. (Strabo, 17.I.13).

Targ, R., \& Puthoff, H. (1974, October). Information transmission under conditions of sensory shielding. Nature, 251(5476), 602-607.

Weiant, C. W. (1943). An introduction to the ceramics of Tres Zapotes, Veracruz, Mexico. Smithsonian Bulletin, 139. Smithsonian Institution Bureau of American Ethnology.

Weiant, C. W. (1960, April 13). Parapsychology and anthropology. Manas, 13(15), 3-6. https://www.manasjournal.org/pdf_library/VolumeXIII_1960/XIII-15.pdf 